\title{
The Institutional Foundations of Medicalization: A Cross-National Analysis of Mental Health and Unemployment
}

Article in Journal of Health and Social Behavior · January 2017

CITATIONS

0

3 authors:

Veerle Buffel

Ghent University

16 PUBLICATIONS 33 CITATIONS

SEE PROFILE

Piet F. Bracke

Ghent University

161 PUBLICATIONS 1,485 CITATIONS

SEE PROFILE
READS

110
Jason Beckfield

Harvard University

63 PUBLICATIONS 1,526 CITATIONS

SEE PROFILE

Some of the authors of this publication are also working on these related projects: 
The Institutional Foundations of Unemployment Medicalization

The Institutional Foundations of Medicalization: A Cross-National Analysis of Mental Health and Unemployment*

Veerle Buffel, Ghent University

Ghent University, Department of Sociology, Korte Meer 5. 9000, Ghent, Belgium

Veerle.Buffel@UGent.be

Jason Beckfield, Harvard University

Piet Bracke, Ghent University 


\begin{abstract}
In this study, we question whether the relationship between unemployment and mental health care use, controlling for mental health status, varies across European countries. And whether these differences are patterned by a combination of unemployment and health care generosity. We hypothesize that medicalization of unemployment is stronger in countries where a low level of unemployment generosity is combined with a high level of health care generosity. A subsample of 36,306 working-age respondents from rounds 64.4 (2005-2006) and 73.2 (2010) of the cross-national survey, Eurobarometer, is used. Country-specific logistic regression and multilevel analyses, controlling for public disability spending, changes in government spending, economic capacity, and unemployment rate, are performed. We find that in the majority of the 24 nations, unemployment is medicalized at least to some degree. Moreover, the medicalization of unemployment varies substantially across countries, corresponding to the combination of the level of unemployment and of health care generosity.
\end{abstract}

\title{
Keywords
}

medicalization, employment status, mental health care use, health care generosity, unemployment generosity

As a recent meta-analysis of cross-sectional and longitudinal studies showed, the negative relationship between unemployment and mental health is well established (Paul and Moser 2009), but much less is known about how unemployment translates into the utilization of mental health care (MHC). Few studies have explored the relationship between employment status and health care use, and these use the consumption of health services or medication as a proxy for mental health problems (Schmitz 2011; Virtanen et al. 2008). This is a significant limitation, given that MHC and antidepressant use among the unemployed is not exclusively 
need based (Bijl and Ravelli 2000; Buffel, Dereuddre, and Bracke 2015; Buffel, van de Straat, and Bracke 2015; Yuen and Balarajan 1989). Previous research confirms that the unemployed have higher MHC and medication use than expected based on their mental health status, which has been interpreted as an indication of the medicalization of unemployment (Buffel, Dereuddre, and Bracke 2015; Buffel, van de Straat, and Bracke 2015).

An even more striking limitation of existing research into unemployment, health, and MHC utilization is the lack of cross-national comparative research (Bambra and Eikemo 2009). In the current context of high unemployment rates and health care expenditure in many wealthy democracies, and also austerity policies implemented in many European countries that have led to cutbacks in public expenditures, it is crucial to understand whether, how, and why unemployment drives MHC utilization differently in different nations.

In this study, we investigate first whether the relationship between unemployment and MHC use, controlling for mental health status, varies across European countries. Second, we explore whether these differences across countries are patterned by a combination of unemployment policies as well as health care system characteristics, including disability benefits, which bridge the policy domains of welfare and health care. Third, we analyze how the level of generosity in both policy domains shapes the relationship between unemployment and mental health care use. Analyzing these relationships with data before and after the start of the recent economic recession in Europe, which sparked austerity policies in many countries, allows us to shed light on the role of austerity politics in connecting unemployment and mental health (Beatty and Fothergill 2015).

We use cross-national survey data from the Eurobarometer wave $64.4(2005 / 2006)$ and 73.2 (2010), because these data are uniquely suited for our purpose: the samples are nationally representative, the institutional variation is vast (given that the Eurobarometer 
includes dozens of countries), and most importantly, unlike other cross-national surveys the Eurobarometer includes questions about employment status, mental health status, and MHCutilization. Prior research on the connection between unemployment and mental health has had to use mental health care utilization as a proxy for mental illness, but the Eurobarometer data uniquely allow us to relax the assumption of a close correspondence between MHC utilization and mental illness.

\section{BACKGROUND}

\section{Medicalizing Unemployment and the Gaps in Current Medicalization Research}

Medicalization describes a process by which non-medical (social) problems-such as unemployment-are defined and/or treated as medical problems (Conrad 1992). Hitherto, the lion's share of studies about medicalization has taken a social constructivist approach. The focus is on the construction of new medical categories and its subsequent expansion of medical jurisdiction, such as studies of the medicalization of hyperactivity, menopause, posttraumatic stress disorder and alcoholism (Conrad 2005). Such work has developed an extensive conceptual and empirical literature on the process and effects of medicalization, although the range of institutional contexts within which medicalization has been studied is relatively limited. This limitation has truncated the range of institutional factors that have been considered as potential foundations for medicalization.

Our theoretical contribution to existing medicalization literature integrates insights from comparative political economy research in order to identify the institutional foundations for medicalization. We thus address several limitations of existing research inspired by medicalization theory, as developed by Conrad (1992), and Conrad and Leiter (2004). First, we develop a novel technique for measuring medicalization, building on related crossnational comparative work on medicalization (Christiaens and Bracke 2014; Moloney, 
Konrad, and Zimmer 2011; Olafsdottir 2007; Zheng 2011). Our innovation is to measure and interpret MHC utilization beyond actual need, as an indicator of medicalization that can be compared across societies. In other words, and as presented on Figure 1, if the mental health care use of the unemployed is higher than that of the employed, and this can only partly be ascribed to their poorer mental health status, we see this as an indication of medicalizing unemployment.

As a result, medicalization of unemployment will be explored in one specific domain: the use of medical care in the mental health field. We have to be aware of the fact that medicalization of unemployment can also be examined in other societal areas, such as in national discourses on unemployment as a personal failure, a deviant position or psychological deficit. Moreover, unemployment can also be medicalized in order to create the possibility of relying on the more stable, less stigmatizing and often more generous disability benefits instead of unemployment benefits (Beatty and Fothergill 2005). Labor market inactivity of those who rely on disability benefits for income support is sometimes known as 'hidden unemployment'; Arguments in the literature over the blurry boundary between the inactive and the disabled prevent precise identification of hidden-unemployment effects (Bratsberg, Fevang, and Roed 2010; Koning and van Vuuren 2006). Our analysis addresses this in two ways: first, by excluding respondents who report being out of the labour market due to disability, and second, by controlling for public expenditures on disability benefits using data from Eurostat and other sources.

[Figure 1 around here]

Second, we contribute to the developing cross-national comparative approach to understanding medicalization (Olafsdottir 2007, 2010). Our innovation in this regard, in view 
of the trend toward deinstitutionalization in the European mental health sector (Hermans, de Witte, and Dom 2012), is to relax the assumption that physicians and hospitals are the (only) key actors in medicalization, and to recognize that multiple power actors-the pharmaceutical industry, policymakers, and patients or health care consumers-also contribute to the process of medicalization (Clarke and Shim 2011; Conrad 2005; Conrad and Barker 2010). Third, we advance the integration of medicalization research across levels of analysis (Conrad 2005).

We apply multi-level modeling techniques to evaluate the hypothesis that medicalization, as a cultural transformation that varies across institutional settings, shapes the health behavior of individuals, such as consulting with medical professionals.

In addition, multilevel analysis of data collected before and after the onset of economic recession and austerity policies allows us to address the relation between austerity and the medicalization of unemployment. Previous studies (Antonakakis and Collins 2015; Karamessini and Rubery 2013; Karanikolos et al. 2013; Kondilis et al. 2013; McKee, Karanikolos, Belcher, and Stuckler 2012) have already indicated that cutbacks in government expenditures may have an impact on the employment and unemployment conditions, (mental) health outcomes, and the consumption of health services. Fiscal austerity has for example recently led to a decline in health care access in Greece (Kentikelenis et al. 2011).

\section{Unemployment Generosity and its Relation to Medicalizing Unemployment}

We investigate whether the relationship between unemployment and medical care use is moderated by welfare generosity in the areas of unemployment and health care. Our measure of generosity, taken from Scruggs et al. (2013), captures not only the level of benefit payments, but also the conditionality and strictness of entitlements that affect the level of coverage (e.g., targeted benefits versus universal benefits). Similarly, generosity of health care is the degree to which health care is delivered as a social right of citizenship, rather than 
as something to be purchased in the medical marketplace. In line with the work of Scruggs (2014), who builds on earlier work on decommodification by Esping-Andersen (1990), we use the term 'generosity' to engage with institutionalist research on welfare-state effects on population health (Beckfield et al. 2015), to highlight the improvements in measurement since Esping-Anderson's pioneering work, and to emphasize the use of more recent data and the coverage of more European countries.

Countries characterized by a low level of unemployment generosity are, for example, the United Kingdom (Bambra 2005b; Jensen 2008) and several Eastern European states. In these, the social protection system for the unemployed is relatively weak, with less generous income replacement rates and strict entitlement criteria, which may increase financial stress and lessen the feeling of self-control (Strandh 2001). The maximum duration of a standard unemployment benefit is, for example in the UK, Estonia, Lithuania, Slovakia and Czech Republic, 26 weeks, which is the shortest duration of the European countries included in this study. Thereafter, the unemployed in the UK can only rely on mean-tested benefits. However, it is known that such benefits can be highly stigmatizing (Diderichsen 2002; Eikemo et al. 2008; Rodriguez, Frongillo, and Chandra 2001). The unemployed are often considered to be responsible for their situation (Bambra and Eikemo 2009), which can stimulate self-blame and the perception of having failed and being socially excluded. All these factors may be associated with medicalizing unemployment. As result we can expect that in countries with a low level of unemployment generosity, unemployment will be more strongly related to mental health care use (See Figure 2.a).

[Figure 2.a around here] 
Although a consistent negative relationship between unemployment and well-being, health, and mental health has been observed in previous research (Bambra and Eikemo 2009; Strandh 2001; Wulfgramm 2014), in countries with a high level of unemployment generosity , such as some Scandinavian countries (Esping-Andersen 1987, 1990), the medicalization of unemployment may be weaker. There is strong protection for the unemployed through highly interventionist governments, which value principles such as universalism and social equality (Bambra and Eikemo 2009). In Norway, for example, only 4 weeks of employment are needed to qualify for an unemployment benefit (this is the shortest qualifying period in Europe), while in Germany and Italy this is 104 weeks (two of the longest qualifying periods). In the more generous welfare states, the level of benefits is also relatively high, and since they are not means-tested but rather universalist, stigmatization may be lower. As a result, unemployment may be less stressful and related to reduced negative feelings of selfblame and personal failure. Unemployment may be considered more as a social problem, which requires a structural approach. This expectation is in line with a previous study, which found that mental health problems in Iceland are perceived more as social problems with social solutions, whereas in the United States they are viewed as individual problems requiring an individual approach; and are indeed more medicalized in the US (Olafsdottir 2010).

\section{Health Care Generosity and its Relation to Medicalizing Unemployment}

Institutional conditions and welfare policies may not only have an impact on how unemployment is experienced and how it affects individuals' mental health and demand for MHC and medication, but also on the access to and availability of the resources needed to make medicalization of unemployment possible. Therefore, in addition to the role of unemployment generosity, we also explore the role of health care generosity. 
Although health care is one of the key dimensions of all modern welfare states, it is relatively absent from major welfare-state theories, as is the case with Esping-Andersen's work (Bambra 2005b; Jensen 2008). In response to this limitation, Bambra (2005a, 2005b) introduced the concept of health care decommodification. It covers the provision of care, the degree to which this provision is independent from the market, and the extent to which an individual's access is dependent on their market position. The indicators included in our health care generosity measurement assess the financing, provision, and coverage of the private sector, and are therefore useful indicators of the varied role of the market in a health care system. The larger the size of the private health sector, in terms of expenditure and consumption, the larger the role of the market; and therefore the lower the degree of health care generosity (Bambra 2005a). The UK with $100 \%$ coverage, and only $3.7 \%$ private hospital beds (of the total bed stock) and $1.72 \%$ private health expenditure (\% of the GDP) has a relatively high level of health care generosity, while for example Belgium $(99.0 \%$ covered) and Germany (89.1\% covered) with respectively $61.8 \%$ and $59.3 \%$, private hospital beds and $2.54 \%$ and $2.74 \%$ private health expenditure, have a relatively low level of health care generosity. We can expect that in countries with a high level of health care generosity, the unemployed will be less constrained in their medical care use (See Figure 2.b).

[Figure 2.b around here]

In sum, based on this theoretical framework, we can hypothesize that a combination of low unemployment generosity and high health care generosity-with the UK as an illustration-will trigger the medicalization of unemployment. In this situation, the unemployed will possibly perceive greater stigmatization of and individual responsibility for 
unemployment. These correlates of mental illness, then, may facilitate increased MHC, in generous healthcare systems.

[Figure 3 around here]

In Figure 4, the countries are shown according to their combined unemployment generosity and health care generosity (please see the measurement section below for details). Typical countries characterized by the inverse combination of above-namely with a quite high level of unemployment generosity, while a low level of health care generosity-are Belgium and Bulgaria, the first especially regarding its high unemployment generosity level, and the later concerning its low level of health care generosity. Greece is a typical country with low levels on both generosity measurements-especially following the implementation of austerity policies demanded by the EU and IMF-while the Netherlands, Denmark and France are modal countries with relatively high levels on both generosity measures.

[Figure 4 around here]

\section{DATA AND METHODS}

\section{The Eurobarometer Survey}

The current study uses data from the Eurobarometer rounds 64.4 (2005-2006) and 73.2 (2010), ${ }^{1}$ which includes information about a general population aged 15 and above in more than 20 European Union member states. The European Commission has carried out the Eurobarometer survey since 1973, to monitor public opinion. The Eurobarometer occasionally includes special items, such as questions about smoking, which have been used in health research (e.g. Pampel 2001). To our knowledge, the Eurobarometer is the only 
cross-national survey that combines (a) nationally-representative samples, (b) measurements of mental health status, (c) measurements of MHC utilization, (d) employment status, and (e) broad cross-national institutional variation. The basic sample design used in all countries comprises a multi-stage, random (probability) sample of individuals within households within an area. Interviews were conducted face-to-face in the national language. To ensure nationally-representative samples, post-stratification weights are applied to restore specific town size, age, and gender distributions for the general population in each country, using the most recent census data. For our purposes, it is appropriate for small countries such as Belgium to be weighted the same as large countries such as Germany (Frohlich 2001). Unweighted analyses yield estimations that are more valid and we do not weight the samples according to population size, as the population sizes of the sampled countries are highly heterogeneous ${ }^{2}$. In addition, because our interest is in the institutional foundations of medicalization, in this case national welfare-state policies regarding unemployment and health care. Following precedent in the literature (Bracke et al. 2010; Buffel, Dereuddre, and Bracke 2015), we merge data from East and West Germany, and from Northern Ireland and the rest of the United Kingdom.

The datasets include 24 European countries: Austria, Belgium, Bulgaria, the Czech Republic, Denmark, Estonia, Finland, France, Germany, Greece, Hungary, Ireland, Italy, Latvia, Lithuania, the Netherlands, Poland, Portugal, Romania, Slovakia, Slovenia, Spain, Sweden, and the United Kingdom (UK).

We use a subsample limited to respondents of working age (20-65 years old), which results in 37,477 respondents. Because no variable contains more than approximately $2 \%$ missing values, the accumulated number of missing values is 1,171 . These cases are omitted from the sample. As a result, the final sample contains information for 36,306 respondents. Descriptive statistics and the sample size per country are provided in online Appendix A. 


\section{Measurements}

For the analysis of medical healthcare utilization, two dichotomous outcome variables for medical mental health care use were constructed: contacting a general practitioner (GP) and/or contacting a psychiatrist (each item coded $1=y e s ; 0=$ no).

The main independent variables are employment status and mental health status. Employment status contains three categories: employed (reference group), unemployed, and non-employed. Non-employed includes homemakers, students, retired people, and those unable to work due to illness or disability. Mental health is measured with the five-item version of the Mental Health Inventory (MHI-5), a subscale of the SF-36 Version 2 (Ware and Sherbourne 1992). The scale measures depression and anxiety-related complaints, and ranges from 1 (good mental health) to 5 (poor mental health). If one or two items were missing, mean substitution was applied. The internal reliability of the MHI-5 scale is good (Cronbach's alpha is .803) and there is evidence for its validity (Mchorney, Ware, and Raczek 1993) and comparability across countries (Lehto-Järnstedt 2003).

Age is measured in years. Period is a categorical variable: 2005-2006 and 2010, with 2005-2006 used as the reference category. To examine within-country differences in the provision of health care services, we control for the degree of urbanization using the following categories: ${ }^{3}$ large town (reference category), rural area or village, and small or medium-sized town. This can be considered as a proxy for supply, because the availability of medical professionals may vary from a large city to a more rural area (Saxena et al. 2007). In addition, attitudes concerning MHC may differ by urbanization, with a greater reluctance to seek professional help in rural areas (Hoyt et al. 1997). We also control for marital status (married [reference category], divorced, widowed, or single) and educational level. The respondents were asked at what age they finished full-time education, and the European 
Commission (Eurobarometer) provides a standard categorization for the answers: aged up to 15 (reference category), aged 16-19, and aged 20 and above. This corresponds approximately to primary, secondary, and tertiary education.

At the country level, our central independent variables are the level of unemployment generosity and the level of health care generosity. To construct the unemployment generosity measurement, we rely on Scruggs' updated “unemployment generosity measure” (Scruggs and Allan 2006; Scruggs 2007), ${ }^{4}$ which is an adaptation of Esping-Andersen's $(1987,1990)$ original measurement. Scruggs uses z-scores to combine information on five indicators into a single measurement that facilitates interpretation. The five indicators are: the level of benefits paid to the unemployed (replacement rate), the qualifying period, the duration of benefits payments, the waiting period before entitlement is available, and the percentage of the working-age population covered by the program (see Figure 5). The higher the benefits, the duration of payments, and the coverage, and the shorter the qualifying period and waiting time, the higher the degree of generosity (and vice versa). For more information see: http://cwed2.org/, where his dataset, the CWED2, is also publicly available (Scruggs, Jahn, and Kuitto 2014).

For comparability with Scruggs's measurement, we adapt Bambra's measurement of the decommodification of health care $(2005 a, 2005 b)$ for the construction of our health care generosity measurement, using the same z-score technique to combine the following indicators: ${ }^{5}$ Private health expenditure as a percentage of GDP, private hospital beds as a percentage of total bed stock, the coverage of the population by the public health care system, and household out-of-pocket (OOP) payments as a percentage of the total health expenditure. ${ }^{6}$ The majority of information concerning private health expenditure, private hospital beds, and household OOP payments for health is available at: 
http://data.euro.who.int/hfadb/, and for the coverage percentages, we use data from the OECD (2012).

[Figure 5 around here]

For both country variables, we try to use as much as possible data for the periods 2004-2006 and 2009-201. Data for the year of the interview and the preceding year is used, because the respondents were asked whether they had sought professional help in the year before the interview, and because of the expected time lag. This also results in the best model fit. Both generosity measurements are interval-level variables, which are grand-mean centered.

We also include additional macro-level control variables to guard against residual confounding. The effects of the nature of welfare policies concerning mental health and the MHC use of the unemployed may also partly depend on the condition of the country's labor market and the general economic capacity (GDP per capita) of a country. A short period of income support for unemployed people, for example, may be less associated with high levels of anxiety and insecurity in countries where the level of unemployment is low and unemployment tends to be of short duration, compared with countries with high job insecurity and unemployment rates (Gallie, Kostova, and Kuchar 2001). In addition, we can expect that in countries with low unemployment, it will be less randomly distributed and as a result, will be more frequently considered a personal characteristic or a direct or indirect consequence of health selection. Unemployment will be more stigmatizing, different to the norm, and treated as an individualized problem (Clark et al. 2003), which can be triggers for medicalization. Therefore, GDP per capita (Model 3) and unemployment rates (Model 4) are included in the multilevel analyses as country level control variables. (Information is derived 
from Eurostat). In addition to the generosity scores, GDP and unemployment rates per country are presented in Table 1.

Also disability generosity is included in the models as additional control variable in order to take the possibility of 'hidden unemployment' via relying on disability benefits partly into account. In the literature (Börsch-Supan 2007), we found that generosity in terms of disability benefits are often measured by the level of public spending on disability. This information is available on Eurostat. In addition, although it was not the objective of this study, we cannot completely ignore the current debate about the claim that there is a movement from a passive toward an active welfare state in several European countries (Bonoli 2010). Central to this are Active Labor Market Programs (ALMP) (Knotz 2012; Knotz and Nelson 2013; Powell and Barrientos 2011; Strandh 2001). The level of expenditure on these programs is often used as an indicator for the activation effort of a country (Knotz 2012). Although we are aware that this is an approximate measurement, the expenditure on ALMP (as a percentage of GDP) is also included in the multilevel analysis as control variable.

Based on the economic crisis literature (Antonakakis and Collins 2014, 2015; Karamessini and Rubery 2013; Karanikolos et al. 2013; Stuckler et al. 2009), cuts in government expenditure on domains as health, unemployment, active labor market programs, family and housing, are used as proxy of fiscal austerity. Data for general government final consumption expenditure as a \% of GDP is collected from the World Bank World Development indicators database (WDI). In line with Antonakakis' work (2015), we have divided general government final consumption expenditure by real GDP, as the expenditure measurement might be biased during a period when nominal GDP is falling. Because of a time lag of at least 1 year, information of 2005 for wave 64.4 (2005/2006) and 2009 for wave 73.2 (2010) is used. We calculate the mean government expenditure over the periods per 
country. The way in which the change in government expenditure is operationalized will be explained in the following section, as this is related to the statistical procedure we use. Country scores on the macro-variables are presented in Appendix B.

\section{Estimation}

Our analyses consist of two parts: In the first part (1), the focus is on country specific differences in the mental health care use of the unemployed and how these are patterned by country's combination of unemployment generosity and health care generosity level. In the second part (2), we look for more general trends regarding the impact of the level of unemployment generosity and health care generosity on the relation between employment status and mental health care use, while taking several other important institutional (disability spending, total government spending and change therein) and macroeconomic factors (GDP, unemployment rate) into account.

(1) Based on country-specific logistic regressions, we test the relationship between employment status and MHC use, and to what extent this association can be ascribed to mental health. To compare the MHC use of the unemployed with that of the employed between countries, predicted probabilities (PP) for the unemployed and employed are calculated based on the Odds ratios resulted from the logistic regression analyses ${ }^{7}$. The differences ( $\left.\mathrm{PP}_{\text {unemployed }}-\mathrm{PP}_{\text {employed }}\right)$ between both $\mathrm{PP}$ are presented in Table 2 . The use of PP is preferable to reporting differences in logistic regression coefficients, because PP do not require the assumption that the error variance is identical across countries (Beckfield, Olafsdottir, and Bakhtiari 2013). First, the PP's are based on the models controlled for age, gender, marital status, education and period. Second, they are based on the adjusted models including mental health. The results based on Model 2 are presented in a bar chart (Figure 7) and related to country scores on the generosity measurement of unemployment and of health 
care. We have categorized the countries into 'groups' depending of whether country's score is above or below the median score of all countries included in the study on the unemployment generosity and the health care generosity measure (See Figure 4 above). This has resulted in four groups of countries with a specific combination of scores: a relatively high level on both generosity measures, a relatively low level on both measures, and on one measurement a relatively high score and a low score on the other (and visa verse). The four groups of countries do thus not represent a typology consisting of 4 'types' or are the results of a cluster analysis. They are just a pragmatic way to present our country specific results, which make it easier to discuss them in relation to the level of unemployment generosity and health care generosity.

(2) In addition, to actually test whether unemployment and health care generosity have a significant moderating effect on the relationship between employment status and MHC use-irrespective of mental health-logistic multilevel analyses are performed, including cross-level interaction effects of employment status and the two generosity measurements. Multilevel analysis enables to take the clustering of our data in periods as well as countries into account. However two periods (2005/2006 and 2010) are not enough to use period as a separate level, and we face thus, like most repeated cross-sectional surveys, a problem of obtaining an adequate number of higher-level units at the period level (Van der Bracht and Van de Putte 2014). But, given the cross-national nature of the Eurobarometer, there is a solution to this lack of sufficient repeated waves, as has previously been described by Fairbrother (2014): considering the clustering of different waves clustered within countries. National-level time-series cross-sectional data has the advantage that it enables simultaneously modeling cross-sectional (or structural) effects that explain between-country differences, and longitudinal (or change) effects that explain within-country differences over time. 
In sum, as you can see on Figure 6, respondents, as units of the individual level (level 1), are nested within country-years ranging from 2005/2006 to 2010 at the period level (level 2), which are in turn nested within countries (level 3). To control for austerity measurements, we have estimated an additional model, where we take the average level of government expenditure into account as well as the change in expenditures. To include longitudinal (or change) effects at the period level and cross-sectional (or structural) effects of government expenditure at the country level in the same model, the longitudinal effects are group-mean centered, as described by Fairbrother (2014). Group-mean centering implies that the variables are measured as deviations from the group-mean, in this case the country mean of the government expenditure over the two periods. The cross-sectional effects at country level are grand-mean centered: the context variables are thus centered on the overall mean. In this way, the longitudinal effects of the change indicators are orthogonal to the cross-sectional effects.

[Figure 6 around here]

Seven models per outcome variable (GP and psychiatrist consultations) will be estimated: Model 1 includes only the individual variables, without controlling for mental health, in Model 2 mental health is added, Model 3 contains the moderation effect of unemployment and health care generosity, controlled for GDP and in Model 4, 5 and 6, we include each time another macro-control variable, respectively unemployment rate, public disability spending and ALMP expenditures. In the last model (Model 7), the austerity effects are estimated.

All models are estimated in the statistical software package MLwiN using Markov Chain Monte Carlo (MCMC) estimation procedures, as this approach has been shown to be 
robust, particularly when including cross-level interactions (Stegmueller 2013). We only consider random intercept models, as the random slopes are not significant.

The results (OR and 95\% Confidence Interval) are presented in Table 3 for GP consultations and Table 4 for psychiatrist consultations.

\section{RESULTS}

First, we briefly examine the descriptive results, shown in Appendix A. The results confirm that in every European country, the unemployed have significantly worse mental health than the employed (tested by one-way ANOVA). Linked to the poorer mental health of the unemployed, the percentage of them who contact a GP/psychiatrist for mental health problems is higher than for the employed in most European countries. However, these differences are not significant for several countries, especially with regard to GP consultations (tested by $\mathrm{Chi}^{2}$ ).

The country scores for the unemployment and health care generosity measurements are shown in Table $1^{8}$. By combining them, we categorize the countries into four groups to make discussion of the results easier. In the first group, the countries included score relatively high (above the median) for both dimensions of generosity: Austria, Denmark, Netherlands, Sweden, France and Ireland. The second group contains countries with a relatively high level of unemployment generosity, but a low level of health care generosity: Belgium Germany, Portugal, Spain, Latvia, and Bulgaria.

"Table 1 About Here"

The third group is characterized by low levels of unemployment generosity combined with relatively high levels of health care generosity: The United Kingdom, Slovenia, the 
Czech Republic, Finland, Estonia, and Romania. In this group in particular, we therefore expect to find evidence for the medicalization of unemployment. The fourth group contains countries scoring low for both generosity measurements and only contains Southern and Eastern European countries: Greece, Hungary, Italy, Lithuania, Poland, and Slovakia. As can be seen in the Table 1, also within the groups there are important differences. The UK and Romania are for example in the same group, but the level of protection of the unemployed in the UK is much higher than that of Romania.

The differences between the predicted probabilities of the unemployed vs. the employed for MHC utilization are shown in Table 2. These are adjusted for mental health (Model 2) and presented per country and country group on the bar chart (Figure 7).

"Table 2 About Here"

With regard to GP consultations, it is apparent in Table 2 that in the majority of the countries, the higher likelihood of the unemployed contacting a GP-as observed in Model 1is no longer significant when adding mental health status to the model. The higher predicted probability of MHC utilization of the unemployed only remains significant (controlling for mental health) in Denmark and the Netherlands (group 1), and the UK and Slovenia (group $3)$.

In more than half of the countries-and dispersed over the four groups-the unemployed are more likely to consult physicians than the employed, controlling for the individual-level variables (Model 1, Table 2). However, when also controlling for reported mental health (Model 2), the higher probability of psychiatrist consultations for the unemployed only remains significant in Denmark (group 1), Germany (group 2), and Slovakia (group 4). In Spain, characterized by moderate unemployment generosity and low 
health care generosity (group 2), the unemployed actually have a significantly lower probability of contacting a psychiatrist. As expected, group 3 has the most countries (the UK, Finland, and Slovenia) with a significantly higher predicted probability among the unemployed than the employed, after controlling for reported mental health.

[Figure 7 (Bar chart) around here]

To investigate whether countries' unemployment rate and health care generosity have a significant moderating effect on the relationship between unemployment and medical care use, we examine the results of the multilevel analyses (Table 3). In Model 1, we observe that the likelihood of contacting a GP for mental health problems (OR=1.491; 95\%CI[1.3281.679]) and contacting a psychiatrist $(\mathrm{OR}=2.557 ; 95 \% \mathrm{CI}[2.002-3.232])$ is significantly higher among the unemployed than the employed. After controlling for mental health status in Model 2, we see that the higher likelihood of contacting a GP for the unemployed $(\mathrm{OR}=1.103 ; 95 \% \mathrm{CI}[.976-1.244])$ is no longer significant. For psychiatrist consultations, this is only partly the case. However, the unemployed are still more likely to contact a psychiatrist $(\mathrm{OR}=2.557 ; 95 \% \mathrm{CI}[2.002-3.232])$ than the employed are, controlling for mental health.

Despite the fact that we do not find evidence for medicalization of unemployment via GP consultations in Model 2, in Model 3 the results show that in countries with a high level of health care generosity $\left(\mathrm{OR}_{\text {interation term }}=1.083 ; 95 \% \mathrm{CI}[1.031-1.139]\right)$ and/or unemployment generosity $(\mathrm{OR}=1.071 ; 95 \% \mathrm{CI}[1.007-1.141]))$, the unemployed have a higher likelihood of contacting a GP, controlling for mental health ${ }^{9}$. However, additional analyses performed separately for the countries with low and high unemployment rates (results not presented in table), show that the moderating effect of unemployment generosity is only significant in countries with a lower unemployment rate $(\mathrm{OR}=1.093 ; 95 \% \mathrm{CI}[1.007-1.187])$. Health care 
generosity has also a significant effect on GP consultations for mental health problems of the employed $\left(\mathrm{OR}_{\text {employed }}=1.095 ; 95 \% \mathrm{CI}[(1.014-1.176)\right.$ but this positive effect was significantly lower than that on the mental health care use of the unemployed $\left(\mathrm{OR}_{\text {unemployed }}=1.095 \mathrm{x}\right.$ $1.083=1.186$ ). Contacting a GP, regardless mental health status, is thus also among the employed $(\mathrm{OR}=1.095 ; 95 \% \mathrm{CI}[(1.014-1.176])$ more likely in countries with a higher level of health care generosity. The higher likelihood of contacting a psychiatrist among the unemployed compared to the employed is more pronounced in countries with high generosity of health care $\left(\mathrm{OR}_{\text {interaction term }}=1.081 ; 95 \% \mathrm{CI}[1.011-1.156]\right.$, see Model 3 of Table 4). Health care generosity has no significant effect on the psychiatrist consultations of the employed.

\section{"Table 3 About Here"}

These interaction effects with unemployment and the generosity measurements remain similar when the other control variables unemployment rate, public disability spending, and ALMP spending are taken into account, respectively in Model 4, 5 and 6. There were no significant associations between these macro variables and GP contacts as well as psychiatrist consultations. In the last model (Model 7), where we control for possible austerity effects by including the context and change variable of government expenditures the main results remain significant. However, a positive change in government expenditures has a positive effect on GP-consultations for emotional and psychosocial problems, net of the actual mental health status and the average level of government expenditures $(\mathrm{OR}=1.027$; 95\% CI[1.003-1.052]). This means that in austerity contexts, cutbacks in government expenditures decrease the likelihood of contacting a GP, controlling for mental health. We also tested the interaction effect of change in government expenditures and employment status (results not presented in table) and we found that for psychiatrist consultations, only 
among the employed there is an effect. In countries with a cut in government expenditures, the likelihood of contacting a psychiatrist has decreased among the employed, irrespective of their mental health status $\left(\mathrm{OR}_{\text {employed }}=1.075 ; 95 \% \mathrm{CI}[1.011-1.142]\right)$. There is also a period effect on specialized mental health care use: the likelihood of contacting a psychiatrist is significantly lower in 2010 than in 2005-2006, which can also be interpreted as an association that is consistent with an austerity or recession effect ( $\mathrm{OR}=.792 ; 95 \% \mathrm{CI}[.657-.958])$.

"Table 4 About Here"

\section{DISCUSSION}

In this study, we addressed three research questions: Does the relationship between unemployment and mental health care use, controlling for reported mental health status, vary across European countries? Are these differences patterned by a combination of unemployment and health care generosity? And more generally, how is the level of unemployment generosity and health care generosity linked to the relationship between employment status and mental health care use, when other important institutional factors (public disability spending, changes in government spending, economic capacity, and labor market conditions) are taken into account?

Before discussing the main findings, we note the key limitations of this study. The first limitation is the divergent timing between measurement of unemployment and measurement of MHC utilization. The main independent variable-employment statusindicates the situation of respondents at the time of the interview. However, the items concerning professional care seeking refer to the preceding twelve months, and the period of reference for experiencing depressive feelings is the preceding month. As a result, we cannot 
use time priority to bolster causal inferences. Accordingly, we addressed threats to causal inference in several other ways. Reverse causality is a concern if individuals with poorer health are more likely to be unemployed. Because we separate respondents who were inactive due to illness or disability from those who were unemployed, we reduce this possible reverse causality. The models were also re-estimated separately for countries with high unemployment rates and those with low unemployment rates, because we can expect that in countries with low unemployment rates, selection effects are more likely, as unemployment is less randomly dispersed. However, we did not find evidence consistent with this selection scenario. Nevertheless, with the available data, we are simply unable to confirm the direction of any causal effects. Based on the meta-analysis by Paul and Moser (2009), which also includes information concerning longitudinal studies, we know that the mental health selection effect on unemployment and job searching is relatively weak. Selection bias is possibly also more of a concern when the outcome variable of interest is mental health instead of MHC use, as it is less likely that the use of care has an impact on becoming unemployed, irrespective of mental health.

Two additional limitations are also related to the source of survey data. First, the response rates for waves 64.4 and 73.2 of the Eurobarometer are not available from Eurostat or any other source. We are left with just one tool to address the representativeness of the Eurobarometer surveys: the post-stratification weights, which we do use. Second, income measurement is omitted from the Eurobarometer surveys we use, which prevents us from assessing the role of household material resources in accessing mental health care.

Bearing in mind these limitations, our study produces three main findings. First, in addition to the fact that unemployment is consistently related to poorer mental health and general health (Bambra and Eikemo 2009), we find that in several European countries, unemployment is medicalized at least to some degree. This medicalization, which we 
quantify as the remaining association between unemployment and MHC utilization, after controlling for reported mental health status, varies substantially across national context. In the UK, for example, the higher specialized care consumption of the unemployed compared to the employed remain after controlling for differences in mental health between the employed and unemployed. In Spain, the unemployed have a lower likelihood of contacting a psychiatrist regardless of their poorer mental health.

Second, the variation in the extent of medicalization of unemployment is significantly patterned by a country's level of unemployment generosity, and especially health care generosity. It is the institutional approach to welfare state effects on health (Beckfield et al. 2015; Bergqvist, Yngwe, and Lundberg 2013), whereby unemployment and health care generosity are addressed as separate welfare domains (Kasza 2002; Bambra 2005a), that allows for this insight. In several countries, policy is generous in one domain but not the other. The UK is a good example of a country with a low level of unemployment generosity combined with a high level of health care generosity. Finland, Estonia, the Czech Republic, Romania, and Slovenia also have this combination. Based on our theoretical framework, this combination was hypothesized to create the most favorable institutional conditions for medicalizing unemployment. In line with this hypothesis, we found indeed that in the UK, Slovenia, Finland and Estonia, MHC utilization among the unemployed is significantly higher than expected based on their mental health, at least for one type of medical care (GP or psychiatrist consultations). Romania and the Czech Republic, however, did not confirm our hypothesis. In Romania this might be explained by its exceptionally low unemployment generosity, which may lead to high financial insecurity among the unemployed. In addition, Romania's high health care generosity is in particular due to a very low provision of private hospitals and low private health expenditure. 
Third, by testing the actual moderating effect of both generosity measurements on the relationship between unemployment and MHC use, a high level of health care generosity in particular is highlighted as an important institutional factor for unemployment medicalization via medical professionals. Bambra's (2005a, 2005b) adjusted and updated health care generosity measurement accentuates the private-public mixture. A large proportion of private health insurance is provided through the workplace (Colombo and Tapay 2004). As a result, in countries with high expenditures on private health insurance and services, the employed often benefit more than the unemployed, for whom it is more difficult to use private services and to obtain private insurance (Colombo and Tapay 2004). Moreover, more private (insurance) expenditure, private service provision (relative to public expenditure and provision), and higher out-of-pocket payments increase social inequality in health care access, especially by harming the most vulnerable (Bambra, Garthwaite, and Hunter 2014), such as possibly the unemployed. By contrast, in countries with high health care generosity, the structural thresholds for contacting a medical professional are lower and the access to and availability of medical resources independent (or minimally dependent) of an individual's position in the labor market and/or their economic capital. This may explain why we find that the unemployed in these countries are more likely to utilize mental health care services. Further qualitative and case specific research could be interesting to get a deeper insight in the proposed mechanisms as possible explanations and to consider other behavioral mechanisms.

With regard to the role of unemployment generosity in the relationship between unemployment and GP consultations, the results contradict our expectations that a low level will trigger medicalization of unemployment. However, additional analyses show that this is only the case in countries with a relatively low unemployment rate. Therefore, in a context where the chances of (health) selection effects are higher, where unemployment is less 
randomly distributed, and where any social-norm effect of unemployment is virtually absent (Clark et al. 2003), higher levels of unemployment generosity may strengthen the medicalization of unemployment via GP consultations. Denmark and the Netherlands have this combination of characteristics, and for these countries, we indeed find higher primary care use by the unemployed than expected based on their mental health. A possible explanation can be found in the pro-poor distribution of GP consultations, also when need is taken into account (van Doorslaer, Koolman, and Jones 2004). Both countries have also in common that they have a flexicurity labour market model. This is characterized by (i) minimal job protection, (ii) generous unemployment benefits, and (iii) extensive use of active labor market policies (Andersen, 2012; Heyes, 2011). Although we have controlled for expenditures on ALMP, specific types of programs, especially those which are compulsory and in some sense paternalistic, can act as an explanation for our findings. Previous work (Heggebo, 2015, 2016) has already indicated that people with ill health and hence more unstable labor market attachment, could be more prone to unemployment in a flexicurity model. Based on our study they also seem to be more vulnerable for medicalizing it.

One of the strengths of the study is that we have taken possible austerity effects into account. In countries such as Greece and several Eastern European countries where there are cutbacks in general government expenditures between 2005 and 2009, the likelihood of contacting a GP for emotional or psychosocial problems was lower compared to countries without a decrease in government expenditures, controlling for individual mental health status and the average level of government expenditures. In several countries, the GP has a gate keeper function (Wendt 2014), referring patients to the most adequate care, which makes this finding especially worrisome. Also other recent studies (De Vogli 2013; Kondilis et al. 2013; Kondilis et al. 2012; McKee et al. 2012) have already warned of austerity effects on health outcomes. 
While we found in general that psychiatrist consultations were reduced in 2010 compared to 2005-2006, only psychiatrist consultations of the employed were less likely in countries with a cut in government expenditures. In previous research (Buffel, van de Straat, and Bracke 2015), we found that in countries with a decline in the GDP growth rate (as indicators of the strength of the recession) the employed are less likely to contact a psychiatrist, controlling for their mental health. A possible explanation for the findings that the austerity effect and the crisis effect only applies to working people may be that the employed may avoid specialized care use for fear of being labeled as sick and thus acquiring a treatment stigma (de Belvis et al. 2012). In slack labor markets, such stigma could more easily result in job loss (Gene-Badia et al. 2012), perhaps especially in countries most strongly affected by the economic crisis and austerity policies.

In addition, our models incorporated the level of public disability spending, as studies have already observed that a high level of spending (especially in countries with less generous unemployment benefits) can lead to 'hidden unemployment', which can also be interpreted as a kind of medicalization of unemployment via relying on disability benefits. Future research is needed to disentangle more directly this part of medicalization of unemployment, as has already been done for 'the pathologization of poverty' (Hansen, Bourgois, andDrucker 2014) or 'monetizing illness' (O'Brien 2015)

Finally, related to the recent activation debate, some researchers are also focusing on the shifting balance between the rights and responsibilities of the unemployed and the growing conditionality requirements for unemployment benefits (Knotz 2012; Knotz and Nelson 2013). We need to be cautious about our results in this regard, because Knotz argues that if there is increasing conditionality, generosity scores will be less accurate (Knotz 2013). For example, if there is a reasonably generous unemployment benefits system, but the unemployed cannot refuse certain jobs without losing their entitlements, generosity is not that 
high, as it refers to the fact that the benefit claimants are more dependent on the labor market. This may be a possible explanation for why we find convincing support for the expected positive relation between health care generosity and medicalizing unemployment, and less support for the hypothesized negative relation with unemployment generosity.

\section{Acknowledgments}

This paper is presented at the Special interest meeting of ESHMS (2015), Trondheim, Norway, 03-04 September, 2015.

\section{Notes}

1. As a test for the validity of the data, we calculated the correlation between countries' unemployment rates derived from the Eurobarometer data, and the Eurostat national data (une_rt_a). The correlation is .789 (wave 2010) and .813 (wave 2005-2006). Additionally, we compared the Eurobarometer data (2005/6-2010) with the waves for 2006-2012 of the European Social Survey, which also include information about mental health (however, not on MHC use) and employment status (per country). The correlations are relatively high (see additional material Table A for more detailed information).

2. Frohlich and colleagues (2001), they conclude that when the aggregated units, make sense, theoretically as units, in our case countries, it is more appropriate to carry out the analyses without weighting by the size of the unities. Unweighted analyses yield estimations that are more valid. Frohlich and colleagues (2001) also indicate that they know of no studies showing that the size of the population or a country, in itself affects the health status and need for health care services of the population. Hence, they state that it is not appropriate to weight analyses by the size of the population. 
3. Type of community is only included as a control variable in the multilevel analyses, as the country-specific samples are too small to control in the country-specific logistic analyses; also for this additional variable.

4. For some countries (especially Eastern and Central European), the unemployment generosity index was not available; only the separate indicators. We calculated the index for these countries based on the formula of Scruggs (Scruggs, Jahn, and Kuitto 2014). As a validity check, we did the same for the countries for which we have the unemployment generosity score. The correlation between our own calculations and Scruggs' scores was nearly $1(\mathrm{r}=.987)$.

5. Bambra's measurement $(2005 \mathrm{a}, 2005 \mathrm{~b})$ is only constructed based on the initial OECD

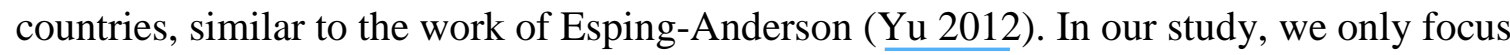
on European countries. As a result, there is less variation in the indicator of coverage, as almost every European country has a full coverage rate (near 100\%). In addition, several Central and Eastern European countries are included in our study. For these countries, Bambra's measurement could give an incorrect reflection of the real situation. Based on her three indicators of decommodification, some Central and Eastern European countries have relatively high scores (see additional information in Appendix B), compared with other countries such as the Netherlands, Belgium, and Germany. This can mainly be ascribed to the fact that some of them still have very little private health care provision in terms of hospital beds ( $\underline{\mathrm{Yu} 2012}$ ), despite the general trend toward privatization (King, Hamm, and Stuckler 2009). Nevertheless, it is known that their health care systems are less developed, especially concerning MHC services (Eikemo et al. 2008; WHO 2005, 2011). The process of privatization in these countries has in particular led to higher OOP payments, which restricts the accessibility of health care services for the more vulnerable groups, such as the unemployed (King, Hamm, and Stuckler 2009). Research has 
observed that the proportion of private health insurance spending is not necessary related to household OOP spending as a proportion of total expenditure on health (QuesnelVallée et al. 2012). For example, in Estonia, Poland, and Hungary, expenditure on private health insurance is almost nonexistent, but OOP payments are relatively high (QuesnelVallée et al. 2012). This is a good indicator for assessing the accessibility of health care services and detecting financial barriers. Further, the increase in OOP payments and patients' fees is related to greater social inequality in the access to health care (Bambra, Garthwaite, and Hunter 2014). Therefore we add this indicator, measured as the household OOP payments as percentage of the total health expenditure, to Bambra's health care decommodification measurement.

6. By measuring the indicator in this way, we avoid the problem that it will also be an indicator of use, such as our outcome variable.

7. The following formula is used: Predicted probability of the employed $=[\exp (a+b 1 X 1+$ $\mathrm{b} 2 \mathrm{X} 2)] /[1+\exp (\mathrm{a}+\mathrm{b} 1 \mathrm{X} 1+\mathrm{b} 2 \mathrm{X} 2)]$. To compute the PP with this formula, we have used the mean score for the metric independent variables, and the proportions for the categorical variables.

8. In Table 2, the coefficients for unemployed mental health status compared with those of the employed are also shown, controlled for age, gender, education, period, and marital status. The results are similar to these of the bivariate analyses (comparing means and ANOVA tests).

9. Second-order interactions (unemployment generosity $\mathrm{x}$ health care generosity $\mathrm{x}$ employment status) are insignificant for the three outcome variables. 


\section{References}

Antonakakis, Nikolaos and Alan Collins. 2014. "The impact of fiscal austerity on suicide: On the empirics of a modern Greek tragedy." Social Science \& Medicine 112:39-5 .

Antonakakis, Nikolaos and Alan Collins. 2015. "The impact of fiscal austerity on suicide mortality: Evidence across the 'Eurozone periphery'”. Social Science \& Medicine 145:63-78.

Andersen, Torben. M. 2012. “A Flexicurity Labour Market in the Great Recession: The Case of Denmark." Economist-Netherlands 160(2): 117-14

Bambra, Clare. 2005a. "Worlds of Welfare and the Health Care Discrepancy." Social Policy \& Society 4(1):31-41.

Bambra, Clare. 2005b. "Cash Versus Services: 'Worlds of Welfare' and the Decommodification of Cash Benefits and Health Care Services.” Journal of Social Policy 34:195-213.

Bambra, Clare and Jason Beckfield. 2012. "Institutional Arrangements as Candidate Explanations for the US Mortality Disadvantage.” Prepared for the NAS/IOM panel on Understanding International Health Differences in High-Income Countries.

Bambra, Clare and Terje Eikemo. 2009. "Welfare State Regimes, Unemployment and Health: A Comparative Study of the Relationship between Unemployment and Self-Reported Health in 23 European Countries." Journal of Epidemiology and Community Health 63(2):92-8.

Bambra, Clare, Kayleigh Garthwaite, and David Hunter. 2014. "All Things Being Equal: Does It Matter for Equity How You Organize and Pay for Health Care? A Review of the International Evidence.” International Journal of Health Services 44(3):457-77.

Beatty, Christina and Steve Fothergill. 2005. "The diversion from 'unemployment' to 'sickness' across British regions and districts.” Regional Studies 39(7):837-854. 
Beatty, Christina and Steve Fothergill. 2015. "Disability Benefits in an Age of Austerity." Social Policy \& Administration 49(2):161-181.

Beckfield, Jason, Clare Bambra, Terje Eikemo, Tim Huijts, Courtney McNamara, and Claus Wendt. 2015. "Towards an Institutional Theory of Welfare State Effects on the Distribution of Population Health.” Social Theory \& Health (published online).

Beckfield, Jason, Sigrun Olafsdottir, and Elyas Bakhtiari. 2013. "Health Inequalities in Global Context." American Behavioral Scientist 57(8):1014-39.

Bergqvist, Kersti, Monica Aberg Yngwe, and Olle Lundberg. 2013. "Understanding the Role of Welfare State Characteristics for Health and Inequalities - an Analytical Review." BMC Public Health 13.

Bijl, Rob V. and Anneloes Ravelli. 200 . "Psychiatric Morbidity, Service Use, and Need for Care in the General Population: Results of the Netherlands Mental Health Survey and Incidence Study." American Journal of Public Health 90(4):602-7.

Bonoli, Giuliano. 201 . "The Political Economy of Active Labor-Market Policy.” Politics \& Society 38(4):435-57.

Börsch-Supan, Axel. 2007. "Work disability, health, and incentive effects." Discussion Papers Series. Mannheim: Mea-Mannheim Research Institute for the Economics of Aging.

Bratsberg, Bernt, Elisabeth Fevang, and Knut Roed. 201 . "Disability in the welfare state: An unemployment problem in disguise.” Econstor 4897.

Buffel, Veerle, Rozemarijn Dereuddre, and Piet Bracke. 2015. "Medicalisation of the Uncertainty? An Empirical Study of the Relationships between Unemployment or Job Insecurity, Professional Care Seeking, and the Consumption of Antidepressants." European Sociological Review (published online) 
Buffel, Veerle, Vera van de Straat, and Piet Bracke. 2015. "Employment Status and Mental Health Care Use in Times of Economic Contraction: A Repeated Cross-Sectional Study in Europe, Using a Three-Level Model.” International Journal for Equity in Health (published online)

Buffel, Veerle, van de Straat, Vera, and Piet Bracke. 2015. "Employment status and mental health care use in times of economic contraction: a repeated cross-sectional study in Europe, using a three-level model." International Journal for Equity in Health.

Christiaens, Wendy and Piet Bracke. 2014. "Work-Family Conflict, Health Services and Medication Use among Dual-Income Couples in Europe.” Sociology of Health \& Illness 36(3):319-37.

Clark, Andrew E. 2003. "Unemployment as a Social Norm: Psychological Evidence from Panel Data." Journal of Labor Economics 21(2):323-51.

Clarke, Adele and Janet Shim. 2011. "Medicalization and Biomedicalization Revisited:

Technoscience and Transformations of Health, Illness and American Medicine.” Pp. 173-99 in Handbook of the Sociologiy of Health, Illness, and Healing: A Blueprint for the 21st Century, Handbooks of Sociology and Social Research, edited by B.A.

Pescosolido, J. K. Martin, J. D. McLeod and A. Rogers. California: Springer Science + Business Media.

Colombo, Francesca and Nicole Tapay. 2004. "Private Health Insurance in OECD Countries: The Benefits and Costs for Individuals and Health Systems." OECD Working Papers. Conrad, Peter. 1992. "Medicalization and Social-Control.” Annual Review of Sociology 18: 209-32.

Conrad, Peter. 2005. "The Shifting Engines of Medicalization.” Journal of Health and Social Behavior 46(1):3-14. 
Conrad, Peter and Kristin K. Barker. 201 . "The Social Construction of Illness: Key Insights and Policy Implications." Journal of Health and Social Behavior 51:S67-S79.

Conrad, Peter and Valerie Leiter. 2004. "Medicalization, Markets and Consumers." Journal of Health and Social Behavior 45:158-76.

De Vogli, Roberto. 2013. "Financial crisis, austerity, and health in Europe." Lancet 382(9890):391-391.

Diderichsen, Finn. 2002. "Income Maintenance Policies - Determining Their Potential Impact on Socioeconomic Inequalities in Health.” Pp. 53-66 in Reducing Inequalities in Health: A European Perspective. London: Routledge. Eikemo, Terrje, Clare Bambra, Ken Judge, and Kristen Ringdal. 2008. "Welfare State Regimes and Differences in Self-Perceived Health in Europe: A Multilevel Analysis.” Social Science \& Medicine 66(11):2281-95.

Esping-Andersen, Gosta. 1987. "Citizenship and Socialism: Decommodification and Solidarity in the Welfare State.” Pp. 73-80 in Stagnation and Renewal in Social Policy: The Rise and Fall of Policy Regimes, edited by Esping-Andersen Gosta and Lee Rainwater. London: Sharpe.

Esping-Andersen, Gosta. 199. The Three Worlds of Welfare Capitalism. Cambridge, UK: Polity Press.

Eurostat. Unemployment rate by sex and age groups - annual average, \% http://appsso.eurostat.ec.europa.eu/nui/show.do?dataset=une_rt_a\&lang=en Fairbrother, Malcolm. 2014. “Two Multilevel Modeling Techniques for Analyzing comparative Longitudinal Survey Datasets." Political Science Research and Methods 2(22):119-14. 
Frohlich, Norman, K. Cough Carriere, Louise Potvin and Anne C. Black. 2001. “Assessing Socioeconomic Effects on Different Sized Populations: To Weight or Not to Weight?” Journal of Epidemiology and Community Health 55(12):913-2 .

Gallie, Duncan, Dobrinka Kostova, and Pavel Kuchar. 2001. "Social Consequences of Unemployment: An East-West Comparison.” Journal of European Social Policy 11(1):39-54.

Hansen, Helena, Philippe Bourgois, and Drucker, Ernest. 2014. "Pathologizing poverty: new forms of diagnosis, disability, and structural stigma under welfare reform.” Social Science \& Medicine 103:76-83.

Heggebo, Kristian. 2015. "Unemployment in Scandinavia during an economic crisis: Crossnational differences in health selection." Social Science \& Medicine, 130:115-124.

Heggebo, Kristian. 2016. "Hiring, Employment and Health in Scandinavia: The Danish 'Flexicurity' Model in Comparative Perspective.” European Societies.

Hermans, Marc. H., Nele de Witte, and Geert Dom. 2012. "The State of Psychiatry in Belgium.” Int Rev Psychiatry 24(4):286-94.

Heyes, Jason .2011. "Flexicurity, employment protection and the jobs crisis." Work Employment and Society, 25(4):642-657.

Hoyt, Danny R., Rand D. Conger, Jorge G. Valde, and Karen Weihs. 1997. “Psychological Distress and Help Seeking in Rural America." American Journal of Community Psychology 25(4):449-7.

Jensen, Carsten. 2008. "Worlds of Welfare Services and Transfers." Journal of European Social Policy 18(2):151-62.

Karamessini, Maria and Jill Rubery. 2013. Women and austerity: the economic crisis and the future for gender equality. 
Karanikolos, Marina, Philipa Mladovsky, Jonathan Cylus, Sarah Thomson, Sanjay Basu, David Stuckler, , . . Martin McKee. 2013. "Financial crisis, austerity, and health in Europe.” Lancet 381(9874):1323-1331.

Kasza, Gregory. 2002. “The Illusion of Welfare Regimes.” Journal of Social Policy 31(2):271-87.Kentikelenis, Alexander, E, Marina Karanikolos, Irene Papanicolas, Sanjay Basu, Martin McKee, and David Stuckler. 2011. "Health effects of financial crisis: omens of a Greek tragedy." Lancet 378(9801):1457-1458.

King, Lawrence, Patric Hamm, and David Stuckler. 2009. "Rapid Large-Scale Privatization and Death Rates in Ex-Communist Countries: An Analysis of Stress-Related and Health System Mechanisms.” International Journal of Health Services 39(3):461-89.

Knotz, Carlo. 2012. "Measuring the 'New Balance of Rights and Responsibilities' in Labor Market Policy." ZeS working papers.

Knotz, Carlo and Moira Nelson. 2013. “Quantifying 'Conditionality': A New Database on Conditions and Sanctions for Unemployment Benefits Claimants." Working paper for the 2013 ESPAne Conference.

Kondilis, Elias, Stathis Giannakopoulos, Magda Gavana, Ioanna Ierodiakonou, Howard Waitzkin, and Alexis Benos. 2013. "Economic Crisis, Restrictive Policies, and the Population's Health and Health Care: The Greek Case." American Journal of Public Health 103(6):973-98.

Kondilis, Elias, Emmanouil Smyrnakis, Magda Gavana, Stathis Giannakopoulos, Theodoros Zdoukos, Steve Iliffe, and Alexis Benos. 2012. "Economic crisis and primary care reform in Greece: driving the wrong way?" British Journal of General Practice 62(598):264-265.

Koning, Pierre and Detlef van Vuuren. 2006. "Disability Insurance and Unemployment Insurance As Substitute Pathways: An empirical analysis Based on Employer Data." 
CPB Netherlands Bureau for Econopmic Policy Analysis: The Hague, the Netherlands

Koning, Pierre, and Detlef van Vuuren. 2006. "Hidden Unemployment in Disability Insurance in the Netherlands; An Empirical Analysis Based on Employer Data." $C P B$ Discussion Paper(69).

Lehto-Järnstedt, Ulla Sisko, and Arpo Aromaa. 2003. Mental Health Measurement in Comprehensive National Health Surveys Helsinki: National Public Health Institute, KTL.

Mchorney, Colleen A., John E. Ware, and A. E. Raczek. 1993. "The Mos 36-Item ShortForm Health Survey (Sf-36) .2. Psychometric and Clinical-Tests of Validity in Measuring Physical and Mental-Health Constructs." Medical Care 31(3):247-63.

McKee, Martin, Marinna Karanikolos, Paul Belcher, and David Stuckler. 2012. “Austerity: a failed experiment on the people of Europe." Clinical Medicine 12(4):346-35 .

Moloney, Mairead Eastin, Thomas R. Konrad, and Catherine R. Zimmer. 2011. "The Medicalization of Sleeplessness: A Public Health Concern.” American Journal of Public Health 101(8):1429-33.

O'Brien, Rourke L. 2015. "Monetizing illness: the influence of disability assistance priming on how we evaluate the health symptoms of others." Social Science \& Medicine 128:31-35. OECD. Employment and Labour Market Statistics: Labour force statistics by sex and age http://dx.doi.org/1 .1787/unemp-table2131-en

Olafsdottir, Sigrun. 2007. "Medicalizing Mental Health: A Comparative View of the Public, Private, and Professional Construction of Mental Illness.” Disertation, Sociology, Indiana University, Bloomington. 
Olafsdottir, Sigrun. 201 . "Medicalization and Mental Health: The Critique of Medical Expansion, and a Consideration of How Markets, National States, and Citizens Matter.” Pp. 239-261, in The Sage Handbook of Mental Health and Illness, edited by Pilgrim David, Rogers Anne, and Bernice Pescosolido: SAGE, London.

Pampel, Fred C. 2001. "Cigarette Diffusion and Sex Differences in Smoking." Journal of Health and Social Behavior 42(4):388-404.

Paul, Karsten I. and Klaus Moser. 2009. “Unemployment Impairs Mental Health: MetaAnalyses.” Journal of Vocational Behavior 74(3):264-82.

Powell, Martin and Armando Barrientos. 2011. "An Audit of the Welfare Modelling Business." Social Policy \& Administration 45(1):69-84.

Quesnel-Vallée, Amélie, Emilie Renahy, Tania Jenkins, and Helen Cerigo. 2012. “Assessing Barriers to Health Insurance and Threats to Equity in Comparative Perspective: The Health Insurance Access Database.” BMC Health Services Research 12(107).

Rodriguez, Eunice, Edward A. Frongillo, and Prakash Chandra. 2001. "Do Social Programs Contribute to Mental Well-Being? The Long Term Impact of Unemployment on Depression in the US." International Journal of Epidemiology 30:163-7 .

Saxena, Sonia, Graham Thornicroft, Martin Knapp, and Harvey Whiteford. 2007. "Global Mental Health 2 - Resources for Mental Health: Scarcity, Inequity, and Inefficiency.” Lancet 370(9590):878-89.

Schmitz, Hendrik. 2011. "Why Are the Unemployed in Worse Health? The Causal Effect of Unemployment on Health.” Labour Economics 18(1):71-78.

Scruggs, Lyle. 2007. "Welfare State Generosity across Time and Space.” Pp. 133-165 in Investigating Welfare State Change: The 'Dependent Variable Problem' in Comparative Analysis, edited by Clasen, Jochen and Nico Siegel. Cheltenham: Edward Elgar. 
Scruggs, Lyle. 2014. Social Welfare Generosity Scores in CWED 2: A Methodological Genealogy. CWED Comparative Welfare Entitlements Datased.

Scruggs, Lyle and Julie Allan. 2006. "Welfare-State Decommodification in 18 OECD Countries: A Replication and Revision.” Journal of European Social Policy 16(1):5572.

Scruggs, Lyle, Detlev Jahn, and Kati Kuitto. 2014. "Comparative Welfare Entitlements Dataset 2. Version 2014-03.” University of Connecticut \& University of Greifswald. Stegmueller, Daniel. 2013. "How Many Countries for Multilevel Modeling? A Comparison of Frequentist and Bayesian Approaches.” American Journal of Political Science 57(3): 748-761. Strandh, Mattias. 2001. "State Intervention and Mental Well-Being among the Unemployed." Journal of Social Policy 30:57-8 .

Van der Bracht, Koen and Bart Van de Putte. 2014. "Homonegativity among first and second generation migrants in Europe: The interplay of time trends, origin, destination and religion.” Social Science Research 48:108-12 . van Doorslaer, Eddy, Xander Koolman, and Andrew M. Jones. 2004. "Explaining Income-Related Inequalities in Doctor Utilisation in Europe.” Health Economics 13(7):629-47.

Virtanen, Marianna, Mika Kivimaki, Jane E. Ferrie, Marko Elovainio, Teija Honkonen, Jaana Pentti, Timo Klaukka, and Jussi Vahtera. 2008. “Temporary Employment and Antidepressant Medication: A Register Linkage Study." Journal of Psychiatric Research 42(3):221-29.

Ware, John E. and Cathy Donald Sherbourne. 1992. "The Mos 36-Item Short-Form Health Survey (Sf-36).1. Conceptual-Framework and Item Selection.” Medical Care 30(6): 473-83.

Wendt, Claus. 2014. "Changing healthcare system types.” Social policy \& administration, 48(7): 864-882. 
WHO. 2005. Mental Health Atlas 2005. Geneva: World Health Organisation.

WHO. 2011. Mental Health Atlass 2011. Geneva: World Health Organisation.

Wulfgramm, Melike. 2014. "Life Satisfaction Effects of Unemployment in Europe: The Moderating Influence of Labour Market Policy." Journal of European Social Policy 24: $258-72$.

Yu, Sam. 2012. "Contribution of Health Care Decommodification Index to the Analysis of the Marginalisation of East Asian Countries in Comparative Welfare Studies." Development and Society 41(2):253-7 .

Yuen, Peter and R. Balarajan. 1989. "Unemployment and Patterns of Consultation with the General-Practitioner." British Medical Journal 298(6682):1212-14.

Zheng, Hui. 2011. "Medicalization as a Rising Rational Myth: Health Implications, Reproduction and Public Response." Ph.D. Sociology - the Journal of the British Sociological Association, Duke University, Durham, North Carolina. 


\section{Author Bios}

Veerle Buffel, postdoctoral researcher in the Department of Sociology at Ghent University. She holds a master degree in Sociology (2012, Ghent University) and a phd in health sociology (2016, Ghent University). She is working on her project financed by BOF. The project studies the relationship between work status, mental health and professional healthcare and psychotropic drug use because of mental health problems from a cross-country and cross-time comparatief perspective. An institutional approach is used to assesse the impact of social policies and characteristics of the health care system. In addition, attention is paid to job insecurity and gender, age and cohort differences.

Jason Beckfield, professor in the Department of Sociology at Harvard University. His research investigates the institutional causes and consequences of social inequality. Currently, he is working on three projects: (1) a book about economic inequality in the European Union; (2) a monograph and a series of journal articles that develop an institutional theory of stratification, with a substantive focus on population health; and (3) collaborative publications, many co-authored with $\mathrm{PhD}$ students, that investigate long term trends in the development of political economy.

Piet Bracke, professor in the Department of Sociologyat Ghent University. His research focuses on gender issues and the sociology of the family; social epidemiology from a comparative perspective; mental health, mental health services research are important fields of research too. He is a member of the executive committee of the European Society of Health and Medical Sociology (ESHMS), a member of the Scientific Advisory Board of the European Social Survey. 


\section{Tables}

Table 1: Country scores on the generosity measurement of unemployment and health care, and countries' national unemployment rate and GDP

\begin{tabular}{|c|c|c|c|c|c|c|}
\hline & & Country & $\begin{array}{l}\text { Unemployment } \\
\text { generosity } \\
\text { (a) }\end{array}$ & $\begin{array}{l}\text { Health care } \\
\text { generosity } \\
\text { (b) }\end{array}$ & $\begin{array}{c}\text { Unemployment } \\
\text { rate } \\
\text { (c) }\end{array}$ & $\begin{array}{l}\text { GDP per } \\
\text { capita } \\
\text { (c) }\end{array}$ \\
\hline \multirow{6}{*}{1} & \multirow{6}{*}{$\begin{array}{l}\text { High unemployment } \\
\text { generosity and } \\
\text { high health care } \\
\text { generosity }\end{array}$} & Austria & 1.42 & 12.04 & 5.5 & 31450 \\
\hline & & Denmark & 1.60 & 15.24 & 5.4 & 39400 \\
\hline & & The Netherlands & 11.94 & 14.12 & 5.3 & 33100 \\
\hline & & Sweden & 1.08 & 13.52 & 7.8 & 32250 \\
\hline & & France & 11.24 & 13.50 & 9.0 & 28300 \\
\hline & & Ireland & 1.64 & 13.39 & 7.0 & 37500 \\
\hline \multirow{6}{*}{2} & \multirow{6}{*}{$\begin{array}{l}\text { High unemployment } \\
\text { generosity and } \\
\text { low health care } \\
\text { generosity }\end{array}$} & Belgium & 13.72 & 9.45 & 8.3 & 30300 \\
\hline & & Germany & 1.30 & 9.89 & 9.7 & 28000 \\
\hline & & Portugal & 1.50 & 9.31 & 9.1 & 15250 \\
\hline & & Spain & 11.04 & 1.70 & 12.7 & 21900 \\
\hline & & Latvia & 11.35 & 8.30 & 13.1 & 7200 \\
\hline & & Bulgaria & 11.55 & 7.46 & 9.7 & 3800 \\
\hline \multirow{6}{*}{3} & \multirow{6}{*}{$\begin{array}{l}\text { Low unemployment } \\
\text { generosity and } \\
\text { high health care } \\
\text { generosity }\end{array}$} & The UK & 8.70 & 15.77 & 5.7 & 28350 \\
\hline & & Slovenia & 9.51 & 14.79 & 6.2 & 15850 \\
\hline & & The Czech Republic & 9.73 & 15.95 & 7.6 & 11900 \\
\hline & & Finland & 9.22 & 13.10 & 8.5 & 31150 \\
\hline & & Estonia & 8.37 & 12.94 & 1.5 & 9350 \\
\hline & & Romania & 5.68 & 14.45 & 7.2 & 4750 \\
\hline \multirow{6}{*}{4} & \multirow{6}{*}{$\begin{array}{c}\text { Low unemployment } \\
\text { generosity and } \\
\text { low health care } \\
\text { generosity }\end{array}$} & Greece & 7.38 & 7.39 & 1.1 & 19050 \\
\hline & & Hungary & 7.59 & 11.62 & 7.8 & 8950 \\
\hline & & Italy & 5.64 & 11.72 & 7.8 & 24850 \\
\hline & & Lithuania & 7.51 & 11.62 & 11.0 & 7350 \\
\hline & & Poland & 6.79 & 11.08 & 15.0 & 7250 \\
\hline & & Slovakia & 7.50 & 11.49 & 15.6 & 9350 \\
\hline
\end{tabular}

Note: Source (a) CWED 2 data (generosity unemployment index; for countries without information on index, own calculations via Scruggs formula based on information of CWED 2 on the separate indicators); (b) Data from Eurostat, OECD and WHO, own calculations via formula of Scruggs; (c) Eurostat 
Table 2: Mental health and MHC use by the unemployed compared with the employed per country

\begin{tabular}{|c|c|c|c|c|c|c|c|c|c|c|c|c|}
\hline & & & \multicolumn{3}{|c|}{ Mental Health } & \multicolumn{2}{|c|}{$\begin{array}{c}\text { GP } \\
\text { consultations }\end{array}$} & \multicolumn{5}{|c|}{$\begin{array}{l}\text { Psychiatrist } \\
\text { consultations }\end{array}$} \\
\hline & & & $\mathrm{b}^{1}$ & sig. & M1 & sig. & M2 & sig. & M1 & sig. & M2 & sig. \\
\hline \multirow{6}{*}{1} & \multirow{6}{*}{$\begin{array}{l}\text { High unemployment } \\
\text { generosity and } \\
\text { high health care } \\
\text { generosity }\end{array}$} & Austria & -.471 & $* * *$ & .122 & $* * *$ & .028 & & .032 & $* *$ & .007 & \\
\hline & & Denmark & -.258 & $* * *$ & .113 & $* * *$ & .077 & $*$ & .054 & $* * *$ & .031 & $* *$ \\
\hline & & Netherlands & -.354 & $* * *$ & .085 & $* *$ & .044 & $\mathrm{a}$ & .039 & $*$ & .012 & \\
\hline & & Sweden & -.269 & $* * *$ & -.028 & & -.052 & & -.011 & & -.012 & \\
\hline & & France & -.173 & $*$ & .016 & & -.010 & & .023 & $*$ & .005 & \\
\hline & & Ireland & -.214 & $* * *$ & .036 & & -.005 & & .006 & $\mathrm{a}$ & .002 & \\
\hline \multirow{5}{*}{2} & High unemployment & Germany & -.253 & $* * *$ & .051 & $* * *$ & .011 & & .061 & $* * *$ & .024 & $* * *$ \\
\hline & generosity and & Portugal & -.322 & $* * *$ & .021 & & -.014 & & .026 & $*$ & .007 & \\
\hline & low health care & Spain & -.170 & $* *$ & .046 & $* *$ & .025 & & -.007 & & -.005 & $*$ \\
\hline & generosity & Latvia & -.225 & $* * *$ & .020 & & .000 & & .006 & $* *$ & .001 & \\
\hline & & Bulgaria & -.256 & $* * *$ & .019 & $\mathrm{a}$ & .009 & & -.004 & & -.002 & \\
\hline \multirow{5}{*}{3} & & United Kingdom & -.341 & $* * *$ & .135 & $* * *$ & .071 & $* *$ & .015 & * & .008 & $\mathrm{a}$ \\
\hline & Low unemployment & Slovenia & -.106 & $\mathrm{a}$ & .070 & $* * *$ & .056 & $* *$ & .017 & & .003 & \\
\hline & generosity and & Czech Republic & -.303 & $* * *$ & .031 & $\mathrm{a}$ & .004 & & .012 & $\mathrm{a}$ & .001 & \\
\hline & generosity & Estonia & -.371 & $* * *$ & .056 & $*$ & .013 & & .028 & $* *$ & .008 & $*$ \\
\hline & & Romania & -.343 & $* * *$ & .023 & & -.007 & & .011 & $\mathrm{a}$ & .003 & \\
\hline \multirow{6}{*}{4} & & Greece & -.324 & $* * *$ & .005 & & -.008 & & .002 & & -.001 & \\
\hline & Low unemployment & Hungary & -.197 & $* *$ & -.010 & & -.019 & & .027 & $*$ & .006 & \\
\hline & generosity and & Italy & -.118 & $\mathrm{a}$ & .030 & & .016 & & -.003 & & -.002 & \\
\hline & low health care & Lithuania & -.166 & $* *$ & .038 & $*$ & .020 & & .017 & $*$ & .005 & \\
\hline & generosity & Poland & -.218 & $* * *$ & -.003 & & -.015 & & .004 & & .001 & \\
\hline & & Slovakia & -.169 & $* *$ & .014 & & -.001 & & .033 & $* *$ & .012 & $*$ \\
\hline
\end{tabular}

${ }^{1} \mathrm{~b}$ : The estimated coefficient of the unemployed (ref. employed) on mental health (MHI-5), while controlling for age, gender, education, period, and marital status.

${ }^{2} \mathrm{M} 1$ : the difference between the predicted probability of the unemployed and the employed, controlled for age, gender, marital status, education, and period.

${ }^{3} \mathrm{M} 2$ : also adjusted for mental health status

The countries are presented in four groups depending of whether country's score is above or below the median score of all countries included in the study on the unemployment generosity and the health care generosity measure (See Figure 4 above)

$\mathrm{p}<.100 * \mathrm{p}<.050 * * \mathrm{p}<.010 * * * \mathrm{p}<.001$ (two-tailed) 
Table 3: Logistic multilevel analysis on GP consultations

\begin{tabular}{|c|c|c|c|c|c|c|c|c|c|c|c|c|c|c|}
\hline & $\begin{array}{l}\text { Model } 1 \\
\text { OR (CI) }\end{array}$ & & $\begin{array}{l}\text { Model } 2 \\
\text { OR }(\mathrm{CI})\end{array}$ & & $\begin{array}{l}\text { Model } 3 \\
\text { OR }(\mathrm{CI})\end{array}$ & & $\begin{array}{l}\text { Model } 4 \\
\text { OR }(\mathrm{CI})\end{array}$ & & $\begin{array}{l}\text { Model } 5 \\
\text { OR (CI) }\end{array}$ & & $\begin{array}{l}\text { Model } 6 \\
\text { OR (CI) }\end{array}$ & & $\begin{array}{l}\text { Model } 7 \\
\text { OR }(\mathrm{Cl})\end{array}$ & \\
\hline $\begin{array}{l}\text { Constant } \\
\text { Employment status } \\
\text { Unemployed }\end{array}$ & $\begin{array}{l}.081 * * * \\
(.066- \\
1.491 * * *\end{array}$ & $.099)$ & $\begin{array}{l}.058^{* * *} \\
(.095- \\
.976^{* * *}\end{array}$ & $.095)$ & $\begin{array}{l}.073 * * * \\
(.057- \\
1.105 * * *\end{array}$ & $.089)$ & $\begin{array}{l}.072 * * * \\
(.057- \\
1.103\end{array}$ & $.090)$ & $\begin{array}{l}.072^{* * *} \\
(.058- \\
1.105\end{array}$ & $.091)$ & $\begin{array}{l}.072 * * * \\
(.057- \\
1.107 * * *\end{array}$ & $.089)$ & $\begin{array}{l}.067 * * * \\
(.050- \\
1.104 * * *\end{array}$ & $.089)$ \\
\hline Nonemployed & $\begin{array}{l}(1.328- \\
1.394 * * * \\
(1.287- \\
1.014 * * *\end{array}$ & 1.514) & $\begin{array}{l}(1.244- \\
1.122 * * * \\
(1.328- \\
1.008 * * *\end{array}$ & 1.244) & $\begin{array}{l}(.977- \\
1.221^{* * *} * \\
(1.124- \\
1.011^{* * *} *\end{array}$ & 1.328) & $\begin{array}{l}(.979- \\
1.222 * * * \\
(1.121- \\
1.011 * * *\end{array}$ & 1.329) & $\begin{array}{l}(.976- \\
1.222 * * * \\
(1.123- \\
1.011 * * *\end{array}$ & $1.330)$ & $\begin{array}{l}(.979- \\
1.224 * * * \\
(1.124- \\
1.011 * * *\end{array}$ & $1.332)$ & $\begin{array}{l}(.977- \\
1.221 * * * \\
(1.121- \\
1.011 * * *\end{array}$ & 1.330) \\
\hline $\begin{array}{l}\text { Gender (ref. men) } \\
\text { Women }\end{array}$ & $\begin{array}{l}(1.011- \\
1.407 * * *\end{array}$ & 1.017) & $\begin{array}{l}(1.014- \\
1.178^{* * *}\end{array}$ & $1.015)$ & $\begin{array}{l}(1.008- \\
1.273^{* * *}\end{array}$ & $1.014)$ & $\begin{array}{l}(1.008- \\
1.273^{* * *}\end{array}$ & $1.014)$ & $\begin{array}{l}(1.008- \\
1.272 * * *\end{array}$ & $1.014)$ & $\begin{array}{l}(1.008- \\
1.273^{* * *}\end{array}$ & 1.014) & $\begin{array}{l}(1.008- \\
1.274 * * *\end{array}$ & 1.014) \\
\hline $\begin{array}{l}\text { Mental health } \\
\text { Period (ref. 2005) } \\
2010\end{array}$ & $(1.308-$ & $1.512)$ & $\begin{array}{l}(1.372- \\
.350^{* * *} \\
(.385- \\
1.117\end{array}$ & $\begin{array}{l}1.372) \\
.385)\end{array}$ & $\begin{array}{l}(1.179- \\
.366^{* * *} * \\
(.349- \\
1.108\end{array}$ & $\begin{array}{l}1.375) \\
.384)\end{array}$ & $\begin{array}{l}(1.180- \\
.366^{* * *} * \\
(.349- \\
1.114\end{array}$ & $\begin{array}{l}1.375) \\
.384)\end{array}$ & $\begin{array}{l}(1.180- \\
.366^{* * *} * \\
(.349- \\
1.117\end{array}$ & $\begin{array}{l}1.373) \\
.384)\end{array}$ & $\begin{array}{l}(1.180- \\
.366^{* * *} * \\
(.349- \\
1.121\end{array}$ & $\begin{array}{l}1.373) \\
.384)\end{array}$ & $\begin{array}{l}(1.182- \\
.366^{* * *} \\
(.349- \\
1.207 * *\end{array}$ & $\begin{array}{r}1.376) \\
.384)\end{array}$ \\
\hline $\begin{array}{l}\text { Unemployment generosity } \\
\text { Health care generosity }\end{array}$ & $(.997-$ & 1.399) & $(.939-$ & 1.317) & $\begin{array}{l}(.917- \\
1.009 \\
(.921- \\
1.095^{* *}\end{array}$ & $\begin{array}{l}1.333) \\
1.103)\end{array}$ & $\begin{array}{l}(.943- \\
1.021 \\
(.936- \\
1.108^{* *}\end{array}$ & $\begin{array}{l}1.334) \\
1.115)\end{array}$ & $\begin{array}{l}(.916- \\
1.006 \\
(.908- \\
1.085^{*}\end{array}$ & $\begin{array}{l}1.326) \\
1.101)\end{array}$ & $\begin{array}{l}(.931- \\
.994 \\
(.900- \\
1.091 *\end{array}$ & $\begin{array}{l}1.336) \\
1.102)\end{array}$ & $\begin{array}{l}(1.000- \\
1.022 \\
(.938- \\
1.103^{*}\end{array}$ & 1.455) \\
\hline $\begin{array}{l}\text { Cross-level inteaction effects } \\
\text { Unemployed x unemployment generosity }\end{array}$ & & & & & $\begin{array}{l}(1.014- \\
1.072^{*}\end{array}$ & 1.176) & $\begin{array}{l}(1.018- \\
1.072^{*}\end{array}$ & $1.208)$ & $\begin{array}{l}(1.005- \\
1.072 *\end{array}$ & 1.171) & $\begin{array}{l}(1.017- \\
1.072^{*}\end{array}$ & $1.166)$ & $\begin{array}{l}(1.022- \\
1.071^{*}\end{array}$ & 1.184) \\
\hline Non-employed $\mathrm{x}$ unemployment generosity & & & & & & 1.141) & & $1.140)$ & & 1.142) & & 1.143) & & 1.142) \\
\hline $\begin{array}{l}\text { Unemployed x health care generosity } \\
\text { Non-employed x Health care generosity }\end{array}$ & & & & & $\begin{array}{l}(.973- \\
1.083^{* *} \\
(1.030- \\
.997\end{array}$ & $\begin{array}{l}1.048) \\
1.140)\end{array}$ & $\begin{array}{l}(.973- \\
1.083^{* *} \\
(1.029- \\
.997\end{array}$ & $\begin{array}{l}1.049) \\
1.141)\end{array}$ & $\begin{array}{l}(.972- \\
1.084^{* *} \\
(1.030- \\
.998\end{array}$ & $\begin{array}{l}1.049) \\
1.141)\end{array}$ & $\begin{array}{l}(.973- \\
1.083^{* *} \\
(1.030- \\
.998\end{array}$ & $\begin{array}{l}1.050) \\
1.138)\end{array}$ & $\begin{array}{l}(.972- \\
1.083^{* *} \\
(1.029- \\
.998\end{array}$ & $\begin{array}{l}1.049) \\
1.140)\end{array}$ \\
\hline $\begin{array}{l}\text { Macro control variables } \\
\operatorname{GDP}(x 1000)\end{array}$ & & & & & $\begin{array}{l}(.965- \\
1.030 \\
(.868-\end{array}$ & $\begin{array}{l}1.031) \\
1.219)\end{array}$ & $(.964-$ & 1.031) & $(.965-$ & $1.032)$ & $(.964-$ & $1.032)$ & $(.966-$ & 1.034) \\
\hline Unemployment rate & & & & & & & $\begin{array}{l}1.007 \\
.938-\end{array}$ & $1.078)$ & & & & & & \\
\hline Public expenditures on disability (x100) & & & & & & & & & $\begin{array}{l}1.015 \\
(.969-\end{array}$ & $1.001)$ & & & & \\
\hline Active Labor Marktet Programs Expenditures & & & & & & & & & & & 1.241 & & & \\
\hline Goverment expenditures & & & & & & & & & & & $(.745-$ & 2.007) & 1.002 & \\
\hline Change goverment expenditures & & & & & & & & & & & & & $\begin{array}{l}(.988- \\
1.028^{*} \\
(1.001-\end{array}$ & 1.016) \\
\hline Variance: Country & $\begin{array}{l}.108 \\
.037- \\
.058 \\
.025-\end{array}$ & $\begin{array}{l}.240) \\
.140)\end{array}$ & $\begin{array}{l}.155 \\
(.050- \\
.064 \\
.028-\end{array}$ & $.343)$ & $\begin{array}{l}.101 \\
(.010- \\
.071 \\
.030-\end{array}$ & $.251)$ & $\begin{array}{l}.102 \\
(.006- \\
.072 \\
(.030-\end{array}$ & $.254)$ & $\begin{array}{l}.106 \\
(.016- \\
.068 \\
(.030-\end{array}$ & $.254)$ & $\begin{array}{l}.101 \\
.017- \\
.068 \\
.029-\end{array}$ & .258 & $\begin{array}{l}.107 \\
(.005- \\
.060 \\
(.025-\end{array}$ & $.260)$ \\
\hline
\end{tabular}

Three level design: individuals ( $n=36,306$; level 1) are nested in country-years ( $n=48$, level 2$)$, which are nested in countries $(n=24$, level 3$)$ 
Table 4: Logistic multilevel analysis on psychiatrist consultations

\begin{tabular}{|c|c|c|c|c|c|c|c|c|c|c|c|c|c|c|}
\hline & & del 1 & Mo & & Mo & & Moc & & Mo & & $\mathrm{Moc}$ & & Mo & \\
\hline & OR & $\mathrm{CI}$ & OR & $\mathrm{CI}$ & OR & $\mathrm{CI}$ & OR & $\mathrm{CI}$ & OR & $\mathrm{CI}$ & OR & $\mathrm{CI}$ & OR & $\mathrm{CI}$ \\
\hline Constant & $.009^{* * * *}$ & & $.006^{* * * *}$ & & $.006^{* * * *}$ & & $.006^{* * * *}$ & & $.006^{* * * *}$ & & $.006 * * *$ & & $.007 * * *$ & \\
\hline Employment status & $(.006-$ & $.013)$ & $(.004-$ & $.009)$ & $(.004-$ & $.009)$ & $(.004-$ & $.009)$ & $(.004-$ & $.009)$ & $(.004-$ & $.009)$ & $(.004-$ & $.013)$ \\
\hline Unemployed & $2.557 * * *$ & $3232)$ & $1.605 * * *$ & 2052 & $1.636^{* * * *}$ & 2 104) & $1.636^{* *}$ & 2090 & $1.637 * * *$ & $2098)$ & $1.642 * * *$ & $2109)$ & $1.644 * * *$ & $2111)$ \\
\hline Nonemployed & $2.560^{* * * *}$ & & $1.998 * * *$ & $2.032)$ & $2.038^{* * *}$ & $2.104)$ & $2.038^{* * * *}$ & 2.0707 & $2.042 * * *$ & $2.070)$ & $2.042 * * *$ & 2.109) & $2.044 * * *$ & 2.1117 \\
\hline Age & $\begin{array}{l}(2.130- \\
1.007\end{array}$ & $3.068)$ & $\begin{array}{l}(1.662- \\
1.001\end{array}$ & 2.401) & $\begin{array}{l}(1.692- \\
1.001\end{array}$ & 2.469) & $\begin{array}{l}(1.687- \\
1.001\end{array}$ & 2.462) & $\begin{array}{l}(1.697- \\
1.001\end{array}$ & 2.457) & $\begin{array}{l}(1.687- \\
1.001\end{array}$ & 2.472) & $\begin{array}{l}(1.689- \\
1.001\end{array}$ & 2.472) \\
\hline Gender (ref. men) & $(1.000-$ & 1.013) & $(.994-$ & 1.009) & $(.994-$ & 1.009) & $(.994-$ & $1.008)$ & $(.994-$ & $1.000)$ & $(.994-$ & $1.008)$ & $(.994-$ & $1.008)$ \\
\hline $\begin{array}{l}\text { Women } \\
\text { Mental health }\end{array}$ & $\begin{array}{l}1.225 * * \\
(1.039-\end{array}$ & 1.457) & $\begin{array}{l}1.043 \\
.881- \\
.246 * * *\end{array}$ & 1.236) & $\begin{array}{l}1.045 \\
(.882- \\
.245^{* * *}\end{array}$ & 1.239) & $\begin{array}{l}1.042 \\
.881- \\
.245^{* * *}\end{array}$ & 1.234) & $\begin{array}{l}1.042 \\
.878- \\
.245^{* * *}\end{array}$ & 1.232) & $\begin{array}{l}1.044 \\
.878- \\
.244 * * *\end{array}$ & $1.240)$ & $\begin{array}{l}1.043 \\
.883- \\
.245^{* * *}\end{array}$ & 1.234) \\
\hline $\begin{array}{l}\text { Period (ref. 2005) } \\
2010\end{array}$ & .820 & & $\begin{array}{l}(.223- \\
.792 * * *\end{array}$ & $.272)$ & $\begin{array}{l}(.223- \\
.791 * * *\end{array}$ & $.270)$ & $\begin{array}{l}(.222- \\
.790 * * *\end{array}$ & $.269)$ & $\begin{array}{l}(.222- \\
.791 * * *\end{array}$ & $.270)$ & $\begin{array}{l}(.222- \\
.794 * * *\end{array}$ & $.269)$ & $\begin{array}{l}(.223- \\
.841\end{array}$ & $.270)$ \\
\hline Unemployment generosity & $(.685-$ & $.981)^{* *}$ & $(.657-$ & $.958)$ & $\begin{array}{l}(.651- \\
1.171\end{array}$ & $.947)$ & $\begin{array}{l}(.647- \\
1.171\end{array}$ & $.951)$ & $\begin{array}{l}(.655- \\
1.115\end{array}$ & $.960)$ & $\begin{array}{l}(.656- \\
1.115\end{array}$ & $.957)$ & $\begin{array}{l}(.688- \\
1.171\end{array}$ & 1.023) \\
\hline Health care generosity & & & & & $\begin{array}{l}(.984- \\
1.084\end{array}$ & 1.394) & $\begin{array}{l}(.984- \\
1.117\end{array}$ & 1.394) & $\begin{array}{l}(.926- \\
1.050\end{array}$ & $1.320)$ & $\begin{array}{l}(.926- \\
1.054\end{array}$ & 1.320) & $\begin{array}{l}(.984- \\
1.058\end{array}$ & 1.394) \\
\hline Cross-level inteaction effects & & & & & $(.951-$ & 1.239) & $(.968-$ & $1.293)$ & $(.924-$ & 1.191) & $(.931-$ & $1.200)$ & $(.935-$ & 1.207) \\
\hline Unemployed $\mathrm{x}$ unemployment generosity & & & & & .940 & & .940 & & .941 & & .940 & & .936 & \\
\hline Non-employed $\mathrm{x}$ unemployment generosity & & & & & $\begin{array}{l}.824- \\
.923\end{array}$ & 1.071) & $\begin{array}{l}. .825- \\
.922\end{array}$ & 1.070) & $\begin{array}{l}(.823- \\
.923\end{array}$ & 1.074) & $\begin{array}{l}. .825- \\
.923\end{array}$ & 1.069) & $\begin{array}{l}. .821- \\
.920\end{array}$ & 1.068) \\
\hline Unemployed $\mathrm{x}$ health care generosity & & & & & $\begin{array}{l}(.842- \\
1.081^{*}\end{array}$ & 1.012) & $\begin{array}{l}(.840- \\
1.081 *\end{array}$ & $1.010)$ & $\begin{array}{l}(.839- \\
1.081 *\end{array}$ & 1.013) & $\begin{array}{l}(.839- \\
1.081 *\end{array}$ & $1.010)$ & $\begin{array}{l}(.839- \\
1.067 *\end{array}$ & 1.011) \\
\hline Non-employed x Health care generosity & & & & & $\begin{array}{l}(1.011- \\
1.015\end{array}$ & 1.156) & $\begin{array}{l}(1.011- \\
1.017\end{array}$ & 1.156) & $\begin{array}{l}(1.011- \\
1.016\end{array}$ & $1.156)$ & $\begin{array}{l}(1.011- \\
1.017\end{array}$ & 1.156) & $\begin{array}{l}(1.009- \\
1.015\end{array}$ & 1.149) \\
\hline Macro control variables & & & & & $(.938-$ & 1.096) & $(.943-$ & $1.097)$ & $(.940-$ & 1.099) & $(.941-$ & 1.099) & $(.939-$ & 1.094) \\
\hline GDP(x1000) & & & & & $\begin{array}{l}1.007 \\
(.748-\end{array}$ & 1.344) & & & & & & & & \\
\hline Unemployment rate & & & & & & & $\begin{array}{l}1.005 \\
(.937-\end{array}$ & 1.186) & & & & & & \\
\hline Public expenditures on disability (x100) & & & & & & & & & $\begin{array}{l}1.032 \\
(.940-\end{array}$ & 1.101) & & & & \\
\hline Active Labor Marktet Programs Expenditures & & & & & & & & & & & $\begin{array}{l}1.872 \\
(.908\end{array}$ & $4.450)$ & & \\
\hline $\begin{array}{l}\text { Goverment expenditures } \\
\text { Change goverment expenditures }\end{array}$ & & & & & & & & & & & & & $\begin{array}{l}.983 \\
(.958- \\
1.031\end{array}$ & 1.012) \\
\hline & & & & & & & & & & & & & $(.993-$ & 1.076) \\
\hline Variance: Country & .245 & & .438 & & .369 & & .354 & & .344 & & .327 & & .345 & \\
\hline County x period & $\begin{array}{l}. .107- \\
.014\end{array}$ & $.539)$ & $\begin{array}{l}(.222- \\
.013\end{array}$ & $.900)$ & $\begin{array}{l}(.175- \\
.015\end{array}$ & $.830)$ & $\begin{array}{l}(.167- \\
.018\end{array}$ & $.787)$ & $\begin{array}{l}(.161- \\
.017\end{array}$ & $.758)$ & $\begin{array}{l}(.151- \\
.016\end{array}$ & $.751)$ & $\begin{array}{l}(.159- \\
.014\end{array}$ & $.730)$ \\
\hline & $(.001-$ & $.107)$ & $(.001-$ & $.107)$ & $(.001-$ & $.100)$ & $(.001-$ & $.117)$ & $(.001-$ & $.112)$ & $(.001-$ & $.106)$ & $(.001-$ & $.145)$ \\
\hline
\end{tabular}

Three level design: individuals ( $\mathrm{n}=36,306$; level 1$)$ are nested in country-years $(\mathrm{n}=48$, level 2$)$, which are nested in countries $(\mathrm{n}=24$, level 3$)$ 


\section{Figures}

Figure 1: Theoretical model at the individual level: medicalization of unemployment

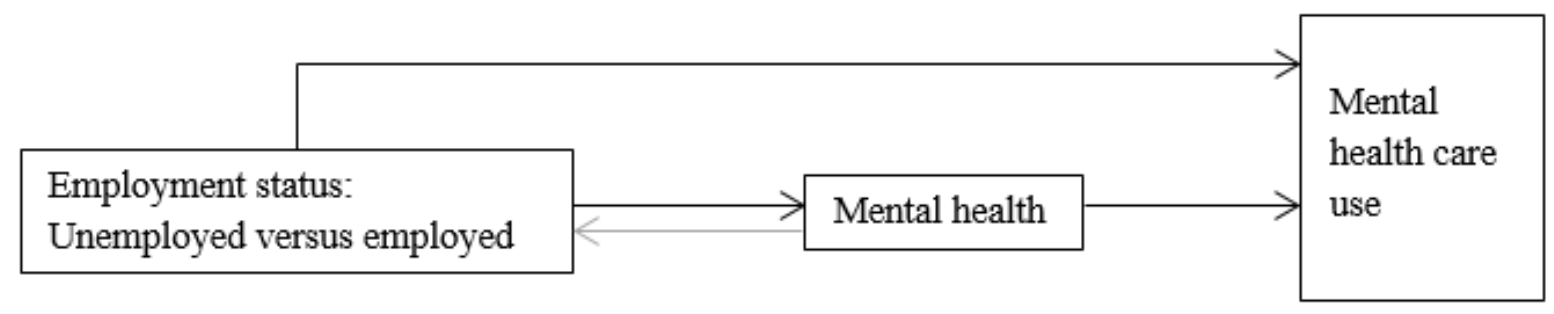

Figure 2.a: Theoretical model of the role of unemployment generosity, a combination of macro-

level and individual level

\begin{tabular}{|c|c|c|}
\hline $\begin{array}{l}\text { Low level of unemployment } \\
\text { generosity: }\end{array}$ & & \\
\hline $\begin{array}{l}\text {-Less protection } \\
\text {-Strict entitlements criteria } \\
\text {-Less generous benefits } \\
\text {-Mean testing } \\
\ldots\end{array}$ & $\begin{array}{l}\text {-Stigmatizing } \\
\text {-Individualization of } \\
\text { responsibility } \\
\text {-Self-blame } \\
\ldots\end{array}$ & $\begin{array}{l}\text { Triggers for medicalization of } \\
\text { unemployment: } \\
\text { Stronger relation between } \\
\text { unemployment and mental health care } \\
\text { use, irrespective of mental health }\end{array}$ \\
\hline
\end{tabular}

Figure 2.b: Theoretical model of the role of health care generosity, a combination of macro-

level and individual level

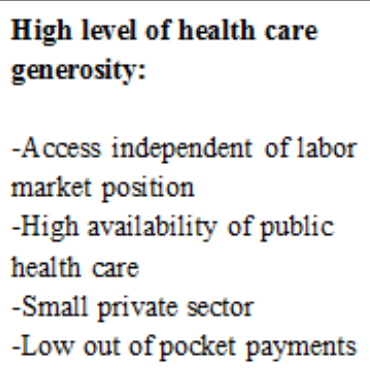


Figure 3: Hypothesis concerning the impact of the combination of unemployment generosity and health care generosity

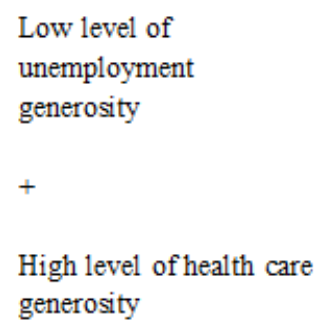

Medicalization of unemployment:

Stronger relation between

unemployment and mental health care use, irrespective of mental health 
Figure 4: Countries positioned in the two-dimensional graph of the unemployment generosity and the health care generosity measure

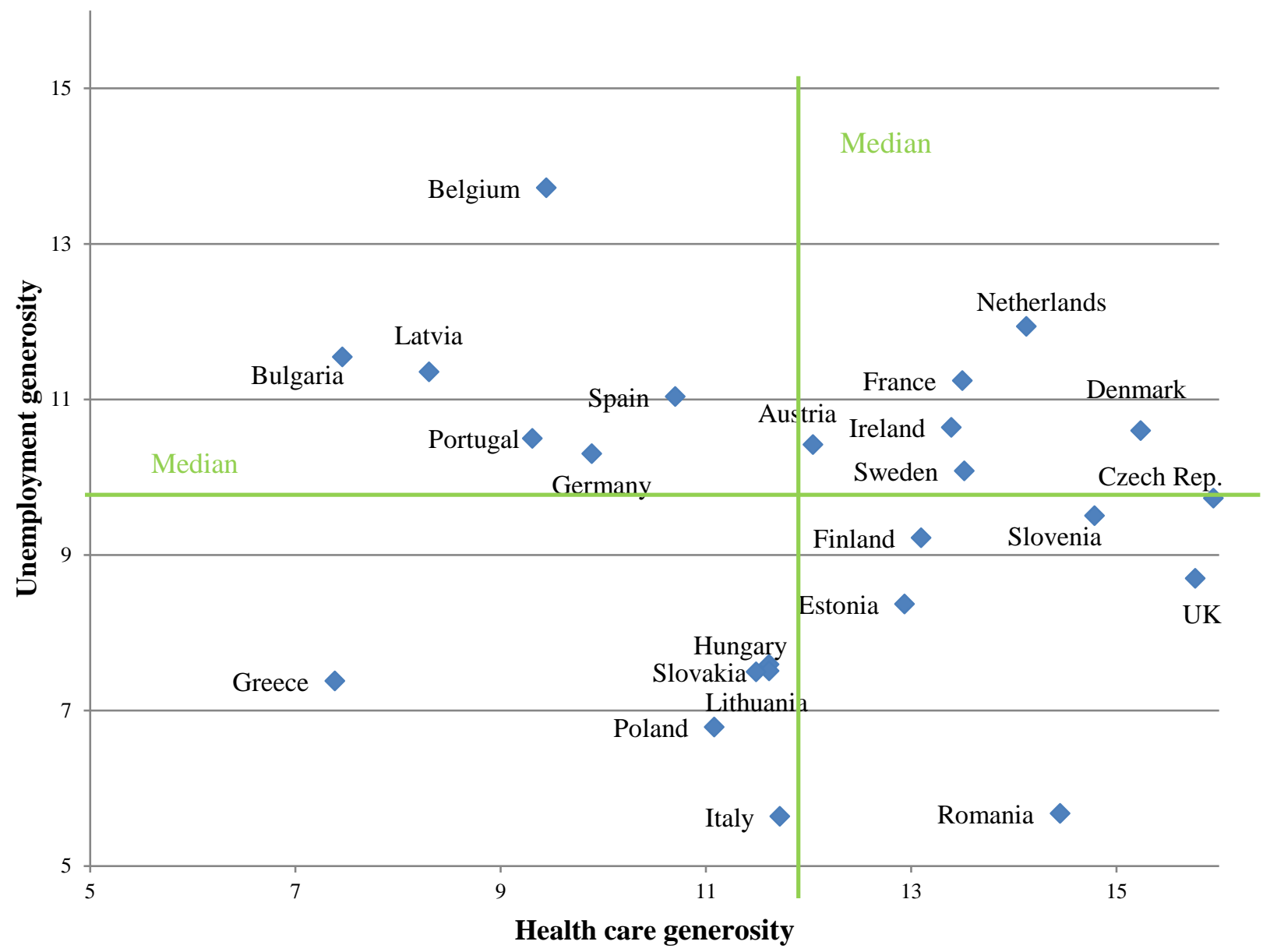

Note: Unemployment generosity scores based on the CWED 2 data (for countries without information on index, own calculations via Scruggs formula based on information of CWED 2 on the separate indicators); Health care generosity score based on data from Eurostat, OECD and WHO, own calculations via formula of Scruggs. 
Figure 5: The indicators of the unemployment generosity measure and the health care generosity measure.

\begin{tabular}{|c|c|c|}
\hline & CASH BENEFITS & HEALTH CARE SERVICES \\
\hline & $\begin{array}{l}\begin{array}{l}\text { Decommodification of labor, focus on } \\
\text { unemployment }\end{array} \\
\text { (Esping-Andersen, 1990) }\end{array}$ & $\begin{array}{l}\text { Decommodification of health care } \\
\text { (Bambra, 2005) }\end{array}$ \\
\hline 1 & $\begin{array}{l}\text { Pre-taxation benefit replacement rates for a } \\
\text { standard worker during the first } 26 \text { weeks of } \\
\text { unemployment }\end{array}$ & $\begin{array}{l}\text { Private health expenditure as a percentage } \\
\text { of GDP - this factor refers to the extent of } \\
\text { private financing by identifying the extend } \\
\text { of a country's total income that is spent on } \\
\text { private health care }\end{array}$ \\
\hline 2 & $\begin{array}{l}\text { Number of weeks employment prior to } \\
\text { qualification for benefit }\end{array}$ & $\begin{array}{l}\text { Private hospital beds as a percentage of } \\
\text { total bed stock - this factor is used to } \\
\text { express the extent of private provisions at a } \\
\text { practical level within a health care system }\end{array}$ \\
\hline 3 & Number of waiting days & $\begin{array}{l}\text { The percentage of the population covered } \\
\text { by the health care system - this shows the } \\
\text { extend of general access provided by } \\
\text { public health care system }\end{array}$ \\
\hline 4 & $\begin{array}{l}\text { Usual number of weeks in which benefit can } \\
\text { be maintained }\end{array}$ & $\begin{array}{l}\text { + Our addition: household OOP payments } \\
\text { as percentage of the total health } \\
\text { expenditure }\end{array}$ \\
\hline 5 & $\begin{array}{l}\text { Percentage of the (relevant) population } \\
\text { covered by the program. }\end{array}$ & \\
\hline
\end{tabular}


Figure 6: Presentation of the three-level design

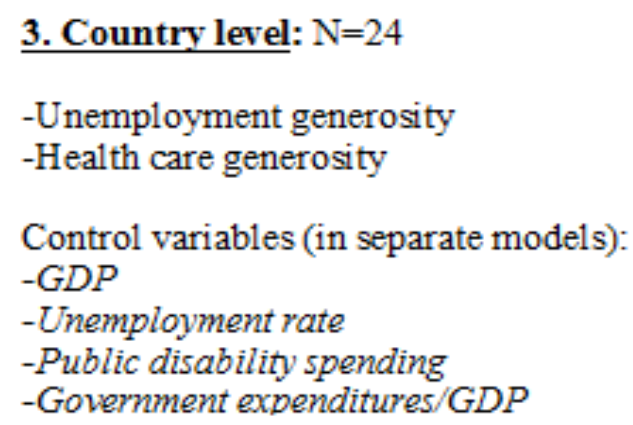

2. Period $x$ country level: $N=48$

-Change in Government expenditures/GDP

1. Individual level: $\mathrm{N}=36306$

Dependent variables

GP-consultations

Psychiatrist consultations

Ind ep end ent variables

Employment status

Mental health

Control variables:

Age, gender, marital status, period,

education, degree of urbanization 
Figure 7: Bar chart, PP unemployed - PP employed on mental health care MHC use per country, all adjusted for mental health and individual control variables

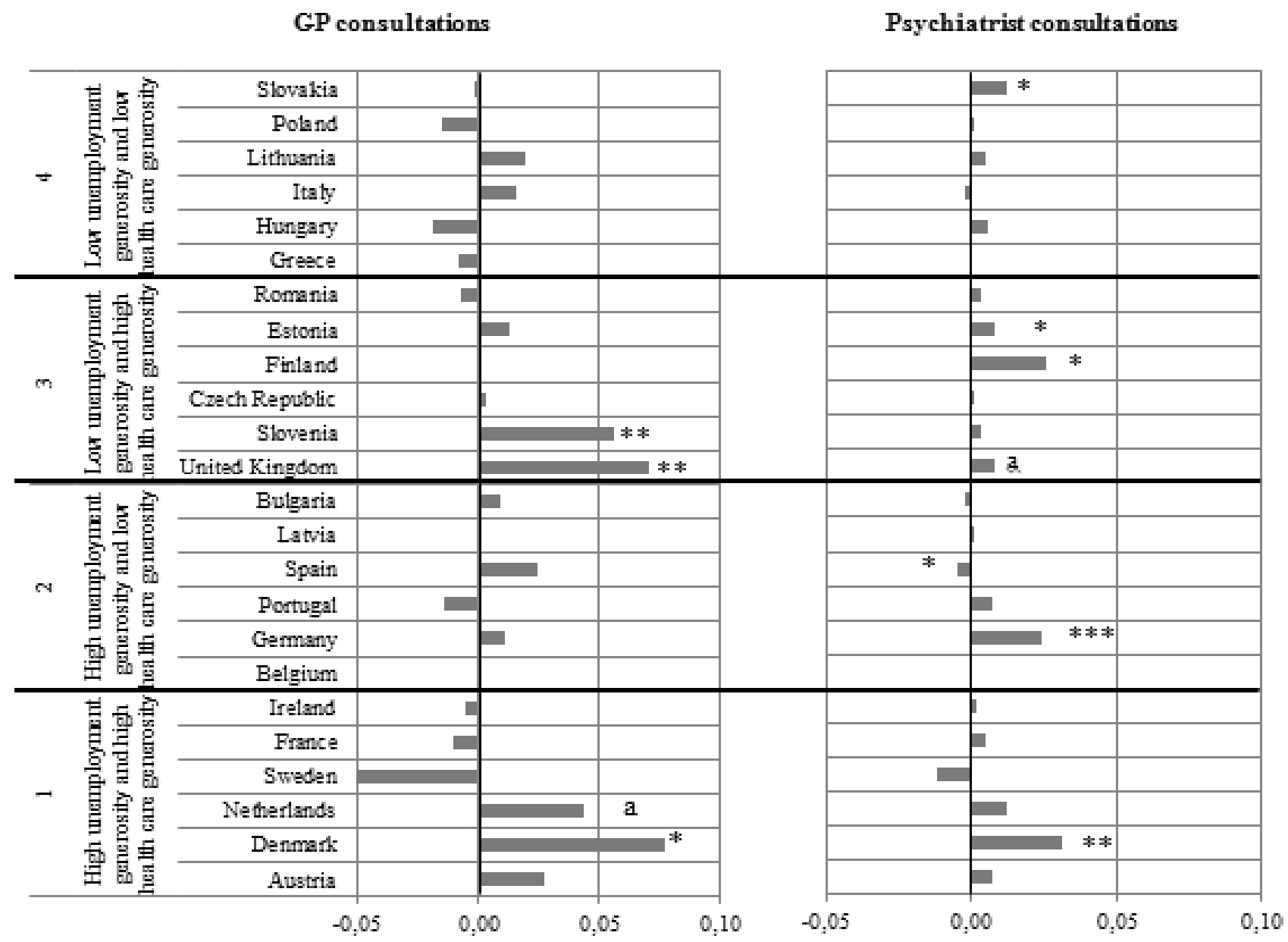

Note: The predicted probabilities are based on the results of the country specific logistic regression analyses. 


\section{Appendix}

Appendix A: Samples size and mental health and mental health care use of the employed and unemployed per country

\begin{tabular}{|c|c|c|c|c|c|c|c|}
\hline \multirow[t]{2}{*}{ Country } & \multirow[b]{2}{*}{ sample size } & \multicolumn{2}{|c|}{ Mean MH-score } & \multicolumn{2}{|c|}{ \% GP consultations } & \multicolumn{2}{|c|}{$\%$ Psychiatrist consultations } \\
\hline & & employed & unemployed & employed & unemployed & employed & unemployed \\
\hline Austria & 1,586 & 3.84 & 3.34 & 9.5 & 22.2 & .9 & 4.8 \\
\hline Belgium & 1,483 & 3.95 & 3.67 & 9.2 & 13.8 & 2.1 & 2.9 \\
\hline Bulgaria & 1,443 & 3.76 & 3.46 & 4.7 & 7.5 & .6 & .6 \\
\hline The Czech Republic & 1,590 & 3.87 & 3.56 & 6.4 & 9.3 & 1.3 & 2.9 \\
\hline Denmark & 1,411 & 4.09 & 3.78 & 11.2 & 23.1 & .7 & 6.6 \\
\hline Estonia & 1,349 & 3.77 & 3.36 & 1.8 & 16.9 & 1.9 & 7.0 \\
\hline Finland & 1,336 & 4.11 & 3.90 & 5.2 & 8.0 & 1.4 & 7.0 \\
\hline France & 1,513 & 3.92 & 3.65 & 1.0 & 13.4 & 1.9 & 3.9 \\
\hline Germany & 2,231 & 3.87 & 3.57 & 7.4 & 13.2 & 1.3 & 5.1 \\
\hline Greece & 1,501 & 3.56 & 3.19 & 4.3 & 5.1 & .9 & 1.3 \\
\hline Hungary & 1,481 & 3.85 & 3.61 & 6.9 & 6.6 & 1.8 & 5.1 \\
\hline Ireland & 1,560 & 3.98 & 3.71 & 9.9 & 12.7 & .2 & 1.7 \\
\hline Italy & 1,598 & 3.55 & 3.43 & 8.7 & 9.4 & .5 & .1 \\
\hline Latvia & 1,451 & 3.61 & 3.35 & 7.6 & 9.5 & .1 & 1.2 \\
\hline Lithuania & 1,369 & 3.71 & 3.50 & 9.1 & 13.5 & 1.3 & 3.5 \\
\hline The Netherlands & 1,623 & 4.11 & 3.66 & 7.4 & 18.8 & 1.8 & 6.2 \\
\hline Poland & 1,472 & 3.87 & 3.57 & 5.6 & 6.7 & .6 & 1.3 \\
\hline Portugal & 1,302 & 3.81 & 3.43 & 11.2 & 14.9 & 2.0 & 5.2 \\
\hline Romania & 1,410 & 3.73 & 3.35 & 19.0 & 2.0 & .1 & 1.1 \\
\hline Slovakia & 1,613 & 3.90 & 3.70 & 12.1 & 13.2 & .5 & 3.7 \\
\hline Slovenia & 1,419 & 3.86 & 3.73 & 4.2 & 12.3 & 1.4 & 3.3 \\
\hline Spain & 1,384 & 3.91 & 3.68 & 5.4 & 11.1 & 1.3 & .5 \\
\hline Sweden & 1,401 & 4.15 & 3.86 & 8.0 & 5.5 & 1.5 & .1 \\
\hline The UK & 1,780 & 3.98 & 3.57 & 8.4 & 25.0 & .5 & 2.4 \\
\hline Total & 36,306 & & & & & & \\
\hline Mean & & 3.87 & 3.57 & 8.43 & 12.99 & 1.11 & 3.23 \\
\hline
\end{tabular}


Appendix B: Additional information, Bambra's health care decommodification

measurement, Public expenditures on disability and ALMP, and Total government spending

\begin{tabular}{|c|c|c|c|c|}
\hline & $\begin{array}{c}\text { Health care generosity } \\
\text { Measure based on only } \\
\text { the } \\
\text { three indicators of } \\
\text { Bambra's index (1) }\end{array}$ & $\begin{array}{c}\text { Public } \\
\text { expenditure } \\
\text { on disability } \\
\text { mean (2) }\end{array}$ & $\begin{array}{l}\text { Public } \\
\text { expenditure } \\
\text { on ALMP } \\
\text { (as \% of } \\
\text { GDP) (3) }\end{array}$ & $\begin{array}{l}\text { Total goverment } \\
\text { spending/ GDP } \\
2009 \text { - (mean of } \\
2005 \& 2009)(4)\end{array}$ \\
\hline Austria & 11.14 & 692.96 & .72 & -.12 \\
\hline Belgium & 9.35 & 588.74 & 1.21 & -.01 \\
\hline Bulgaria & 11.67 & 45.45 & .10 & -13.35 \\
\hline $\begin{array}{l}\text { The Czech } \\
\text { Republic }\end{array}$ & 14.33 & 154.10 & .27 & -2.39 \\
\hline Denmark & 14.03 & 1583.06 & 1.73 & .27 \\
\hline Estonia & 13.21 & 128.07 & .13 & .04 \\
\hline Finland & 13.12 & 1039.91 & .95 & .17 \\
\hline France & 1.90 & 513.99 & .98 & -.11 \\
\hline Germany & 8.50 & 633.37 & .98 & -.03 \\
\hline Greece & 1.14 & 224.95 & .33 & -.12 \\
\hline Hungary & 12.76 & 182.77 & .42 & -.43 \\
\hline Ireland & 12.26 & 403.34 & .75 & .78 \\
\hline Italy & 11.95 & 371.65 & .52 & .10 \\
\hline Latvia & 12.32 & 66.39 & .50 & -4.29 \\
\hline Lithuania & 13.79 & 109.60 & .40 & -2.01 \\
\hline The Netherlands & 11.46 & 812.01 & 1.26 & .27 \\
\hline Poland & 12.32 & 127.62 & .51 & -2.70 \\
\hline Portugal & 1.31 & 325.15 & .68 & -.48 \\
\hline Romania & 14.77 & 64.16 & .09 & -7.53 \\
\hline Slovakia & 12.46 & 109.52 & .30 & -4.15 \\
\hline Slovenia & 13.22 & 273.55 & .33 & -.69 \\
\hline Spain & 11.04 & 335.43 & .82 & .37 \\
\hline Sweden & 12.87 & 1499.58 & 1.10 & .39 \\
\hline $\begin{array}{l}\text { The United } \\
\text { Kingdom }\end{array}$ & 14.04 & 667.45 & .40 & 1.08 \\
\hline
\end{tabular}

Source: 1. Data from Eurostat, OECD, and WHO; own calculations via formula of Scruggs.

2. Eurobarometer data

3. http://ec.europa.eu/europe2020/pdf/themes/24_almp_and_employment_services.pdf.

4. Final consumption expenditure as a \% of GDP is collected from the WDI database; and the general government expenditure is divided by country's real GDP. 
